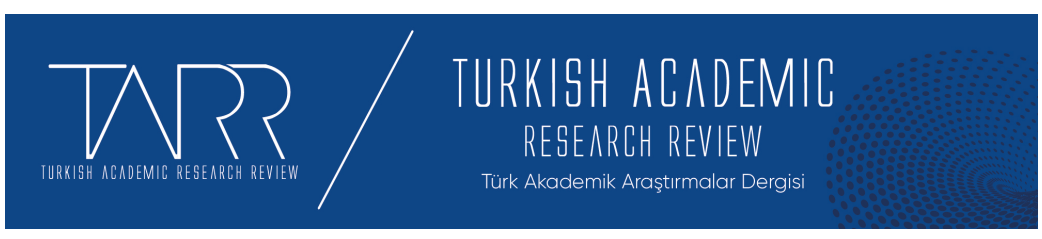

e-ISSN: 2602-2923 Yll/Year: 2021 Cilt/Volume: 6 Sayı/Issue: 3

\title{
Gayesi Bakımından Mucize Çeşitleri
}

Types of Miracles in Terms of Their Purpose

\section{Ali BAKKAL - Hatice TEBER}

Prof. Dr., Akdeniz Üniversitesi İlahiyat Fakültesi/ Fakulty of Divinity Akdeniz University, Antalya / Turkey, alibakkal52@gmail.com, Orcid ID: 0000-0003-4948- 2736

Dr. Öğr. Üyesi, Akdeniz Üniversitesi İlahyat Fakültesi/Fakulty of Divinity Akdeniz University, Antalya / Turkey, haticeteber@akdeniz.edu.tr, Orcid ID: 0000-00034517-0698

\begin{tabular}{r|l} 
Makale Bilgisi & Article Information \\
Makale Türü - Article Type & Araştırma Makalesi / Research Article \\
Geliş Tarihi - Date Received & 29 Temmuz / July 2021 \\
Kabul Tarihi - Date Accepted & 16 Eylül / September 2021 \\
Yayın Tarihi - Date Published & 20 Eylül / September 2021 \\
Yayın Sezonu & Temmuz - Ağustos - Eylül \\
Pub Date Season & July - August - September
\end{tabular}

Atıf / Cite as: Bakkal, A.-Teber, H. (2021), Gayesi Bakımından Mucize Çeşitleri/ Types of Miracles in Terms of Their Purpose. Turkish Academic Research Review, $6 \quad$ (3), 1174-1213. 1 Retrieved from https://dergipark.org.tr/tr/pub/tarr/issue/64962/976182

Intihal / Plagiarism: Bu makale, en az iki hakem tarafından incelenmiş ve intihal içermediği teyit edilmiştir. / This article has been reviewed by at least two referees and confirmed to include no plagiarism. https://dergipark.org.tr/tr/pub/tarr

Copyright (C) Published by Mehmet ŞAHIN Since 2016- Akdeniz University, Faculty of Theology, Antalya, 07058 Turkey. All rights reserved.

Turkish Academic Research Review - Türk Akademik Araştırmalar Dergisi 


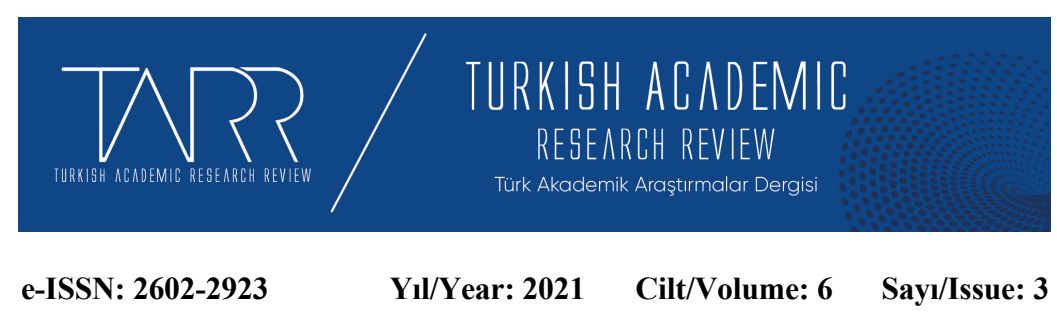

\title{
Gayesi Bakımından Mucize Çeşitleri
}

Ali BAKKAL - Hatice TEBER

$\ddot{O} \mathbf{z}$

Bu makalenin amac1, müfessirlerin Kur'an'da mucize olduğunu kabul ettiği olaylar esas alınarak, gayesi bakımından mucize çeşitlerini ortaya koymaktır. Kelâm kaynaklarında mucize genellikle yapısı bakımından bazı kısımlara ayrılmış, gayesinin peygamber olduğunu iddia eden zatın nübüvvetini ispat etmek olduğu ifade edilmiştir. Oysa Kur'an'da zikri geçen olağanüstü olaylar tek tek incelendiğinde mucizelerin çok daha geniş bir amacı olduğu anlaşılmaktadır. Mucize, olay cinsinden bir varlıktır. Özellikle iradî olaylarda olayın ne olduğundan ziyade, niçin meydana geldiği daha önemlidir. Tarihsel süreçte mucizeler hakkında niçin sorusu sorulmakla birlikte bunun tek bir cevabı üzerinde yoğunlaşılmış, diğer cevaplar göz ardı edilmiş gibidir. Oysa mucizenin anlaşılmasında ve mucize ile ilgili bazı problemlerin çözülmesinde, mahiyeti ve yapısının bilinmesi kadar, gayesinin de bilinmesi büyük önem arzetmektedir. Nitel araştırma özelliğini taşıyan bu incelememiz, amacı açısından temel araştırma olup mucize hakkında teori oluşturmaya yönelik bir çalışmadır. Bu münasebetle Kur'an'daki olağanüstü olaylar analitik yöntemle tek tek incelenerek aralarındaki farklılıklar tespit edilmiş ve amacı açısından dokuz kısma ayrıldığı ortaya konulmuştur.

Anahtar kelimeler: Tefsir, Kur'an, Mucize, Mucizenin gayesi, Mucize çeşitleri.

\section{Types of Miracles in Terms of Their Purpose}

\begin{abstract}
The aim of this article is to reveal the types of miracles in terms of their purpose, based on the events that the mufassirs accept as miracles in the Quran. In theological sources, the miracle is generally divided into parts in terms of its structure, and it is stated that its purpose is to prove the prophethood of the person who claims to be a prophet.However, when the extraordinary events mentioned in the Qur'an are examined one by one, it is understood that miracles have a much broader purpose. A miracle is a being in the form of an event. Especially in voluntary events, it is more important why the event occurred rather than what it is.Although the question of why about miracles has been asked in the historical process, it seems that only one answer has been focused on and other answers have been ignored. However, in understanding the miracle and solving some problems related to the miracle, knowing its purpose is as important as knowing its nature and structure.As a qualitative research, this study is fundamental research in terms of its purpose and is a study to form a theory about miracles. In this connection, the extraordinary events
\end{abstract}

Turkish Academic Research Review - Türk Akademik Araştırmalar Dergisi 
in the Quran are examined one by one with the analytical method, and the differences between them are identified and it is revealed that they are divided into nine parts in terms of their purpose.

Keywords:Tafsir, Quran, Miracle, Purpose of Miracle, Types of Miracles.

\section{Structured Abstract}

In this study, about seventy events mentioned in the Qur'an and generally accepted as a miracle, by the commentators, have been identified. Several of these events were also discussed by the classical commentators, that whether these events were extraordinary or not. However, there is a consensus that that the majority of them were extra-natural. However, those who claim that a miracle cannot be against the laws of nature are not included in this consensus.

Theologians focused on the miracles in terms of their structure, did not attach much importance to the purposes of them. They claimed that the main purpose of the miracle was to prove the prophecy of a person who claims to be a prophet. However, when the miracles are examined individually, it seems very difficult to say that the main purpose of the miracles is to prove prophecy. It is understood that the purpose of 4 of the 70 miracles mentioned in the Qur'an was to inform someone that he was a prophet; of 9 was to prove that someone is prophet; of 7 was to help the believers; of 20 was to help the prophet; of 9 was to protect the prophet, the holy places, and the believers; of 3 was to warn prophet or believers; of 9 was to frighten the disbelievers with the coming of a severe chastisement if they do not believe; of 8 was to destroy the unbelievers; and the purpose of 5 miracles, including 2 as the primary purpose and 3 as the secondary purpose, was to reinforce the principles of faith.

The miracles, which are divided into nine parts in terms of their purposes, can be classified under less groups by grouping declaration or guidance miracles under the subgroup of "declaring and proving that a person is a prophet"; the miracles of help, gratuity, chastity, and warning under the subgroup of "helping the prophets and believers"; the miracles of intimidation and destruction under the subgroup of " frightening and destroying the unbelievers". Accordingly, the purpose of miracles can be examined under four headings including, "proving the prophethood", "helping believers", "destroying the unbelievers", and "reinforcing the principles of faith".

It is also seen that it is not possible to address any miracle under a single class, exclusively. There are three reasons for this:

a. Even though any miracle is not directly considered a miracle of declaration/guidance, all miracles are indirectly a miracle of guidance, since every miracle shows that a person is a prophet. For example, the main purpose of a miracle may be to destroy unbelievers; however, since this event indirectly proves that a person is a prophet, it is also considered a miracle of guidance. However, believing after the causes of destruction appear is not accepted.

b. Sometimes the same miracle appears in different situations for different purposes. For example, the miracles of the white hand and the spectre were first revealed to Moses with the aim of informing that he was a prophet (i'lâm), while the purpose of these miracles was guidance when they were shown to Pharaoh and his followers. 
c. Some miracles have secondary as well as primary purposes. For example, primary purpose of the birds' coming back when Abraham summoned them after they were torn apart and placed on top of a mountain was to reinforce Abraham's belief and the secondary purpose was to reinforce believers' belief in the judgment day.

Considering majority of the miracles were help miracles, we can say that the most important purpose of the miracles was to help the believers. However, regardless of under which subgroup a miracle is addressed, since all miracles have the function of proving that a person is a prophet, we can say that the most important purpose of miracles is to prove the prophethood of a person. However, we must emphasize that it was not the only goal.

In terms of their structure, miracles can be divided into three subgroups including sensible, declarative and mental. The fact that Allah did not accept the demands of heathens from $\mathrm{Hz}$ Muhammed to show a sensible miracle but pointed their attention to the Qur'an, does not show that the Prophet did not have any miracles other than the Qur'an. It can only be said that there is no sensible miracle, like a miracle of guidance, in terms of its purpose. In our study, apart from the miracles of guidance, It can clearly be seen that there are many sensible miracles both shown by the other prophets and $\mathrm{Hz}$ Mohammed.

In order to understand the miracles, it is necessary to evaluate them both in terms of structure and purpose. Evaluations addressing the miracles only in terms of their structures can lead us to wrong conclusions.

\section{Giriș}

\section{Giriş}

Gerek Yüce Allah'a gerek insana ait olsun bütün iradî fiillerde bir gaye ve bir amaç mevcuttur. Amaç olmadan iradenin varlığından söz edilemez. Fahreddin erRâzî (ö. 606/1210) iradeyi, "Bir zorunluluk olmaksızın yapılması veya yapılmaması mümkün olan bir konuda iki taraftan birini tercih etmeyi gerektiren sıfat" şeklinde tanımlamıştır. Buna göre bir şey varsa, onun yapılmasını tercih etmeyi gerektiren bir amaç da vardır. Özellikle iradî fiiller amaçsız olmaz.

Yüce Allah birçok âyette peygamberlere apaçık mucizeler (beyyînât) verdiğini $^{2}$ veya onların apaçık mucizeler getirdiklerini belirtmiş; ${ }^{3} \mathrm{~Hz}$. Peygamber (sav) de bütün peygamberlere mucize verildiğini ifade etmiştir. ${ }^{4}$ Hemen bütün âlimler mucizenin temel amacının, peygamberlik davasında bulunan bir zatın doğruluğunu ispat etmek olduğunu söylemişlerdir. Bu kayıt büyük ölçüde mucize tanımlarına da aksettirilmiştir. Ancak bu durum mucizenin başka amacının

${ }^{1}$ Fahreddin er-Râzî, el-Metâlibü'l- 'âliye mine'l-'ilmi'l-ilâhî, thk. Ahmed Hicâzî es-Sekkā (Beyrut: Dâru'l-Kitâbi'l-Arabî, 1987), 2/175.

2 en-Nahl, 16/44; ; el-Hadîd, 57/25.

3 Bk. Âl-i 'İmrân, 3/183; el-A'râf, 7/101; et-Tevbe, 9/70; Yûnus, 10/74; İbrahim, 14/9; erRûm, 30/47; Fâtır, 35/25; Mü'min, 40/22, 50, 83.

${ }^{4}$ Buhârî, “İ'tișâm”, 1, “Feḍâilü’l-Kurur’ân”, 1; Müslim, “Îmân”, 239. 
olmadığını göstermez. Nitekim Kur'an-1 Kerim'e göre mucize olduğu kabul edilen olaylar incelendiğinde bunların -iddia sahibinin doğruluğunu ispat etmenin yanındafarklı amaçlarının olduğu açıcça görülmektedir. Günümüzde mucize konusunda ortaya çıkan yeni tartı̧̧aların sağlıklı biçimde yürütülebilmesi için öncelikle mucizenin, hem yapısı hem de gayesi bakımından çeşitlerinin dikkate alınması bir zorunluluktur.

$\mathrm{Bu}$ çalışmanın amacı Kur'an'da geçen, müfessirler ve kelamcılar tarafından mucize olduğu kabul edilen olağanüstü olayları esas alınmak suretiyle mucizenin genel amaçlarını tespit; sonra da bu amaçlar doğrultusunda taksim etmektir. Nitel bir araştırma olan bu çalışmamızda doküman analizi yöntemi takip edilmiştir.

Kelâmcılar mucizeyi yaklaşık olarak "Peygamber olduğunu ileri süren kimsenin elinde doğruluğunu kanıtlamak için Allah tarafindan yaratılan hârikulâde olay" "ş̧eklinde tarif etmişlerdir. Kelâm ilminin amacı İslam inançlarını aklî ve naklî delillerle ispat etmek olduğu için mucize konusunu bu zaviyeden bakarak incelemişler ve onun temel amacının bir zatın nübüvvetini ispat olduğunu söylemişlerdir. Kelâmcılar tanımlarına göre sadece peygamberlerin hidayet ve irşad amacıyla gösterdikleri olağanüstü olaylar mucize sayılmaktadır. Ancak Kur'an'da zikri geçen olağanüstü olaylara baktığımızda mucizenin başka amaçlarının da olduğu, hatta doğrudan nübüvveti ispat amaciyla peygamberlerin elinde zuhur eden mucizelerin çok az olduğu görülmektedir. Bunu söylerken tabiî olarak kelâmcıların mucize tanımın benimsemediğimizi de ifade etmiş olmaktayız.

Kelâm kitaplarında harikulâde olaylar mucize, irhâs, keramet, meûnet ve istidrâc olmak üzere beş kısma ayrılmıştır. ${ }^{6}$ Biz, irhâsâtı mucizeye dahil edip olağanüstü olayların mucize ve keramet olmak üzere iki kısımda değerlendirilmesinin daha doğru olacağını düşünüyoruz. Olağanüstü olmaları ve Allah tarafindan yaratılmaları bakımından mucize ile keramet arasında fark yoktur. Ancak üç açıdan aralarında fark vardır: a) Mucizeler peygamberlerin, kerametler velilerin elinde zuhur eder. b) Gerektiğinde peygamber nebî olduğunu ispat için mucize gösterirler. Salih kullar ise veli olduklarını ispat için keramet gösteremezler. c) Bazen peygamberler gösterdikleri mucizelerle inkârcılara karşı meydan okurlar; veliler ise ellerinde zuhur eden kerametin benzerinin getirilmesiyle meydan okumazlar. Aslında kerametler, fil hadisesi gibi peygamberlerle ilgili olmayan

\footnotetext{
${ }^{5}$ Halil İbrahim Bulut, "Mûcize", Türkiye Diyanet Vakfı İslâm Ansiklopedisi (İstanbul: TDV Yayınlar1, 2005), 30/350

${ }^{6}$ Bk. M. Sait Özervarl1, "Hârikulâde", Türkiye Diyanet Vakfi İslâm Ansiklopedisi (İstanbul: TDV Yayınları, 1997), 16/181-183.
}

Turkish Academic Research Review - Türk Akademik Araştırmalar Dergisi 
Allah'ın yarattığı harikulâde olaylardır. Bu açıdan bakıldığında onlara da mucize denilebilir. Ancak bunlara mucize denilmesi halinde keramet olarak bilinen olaylarla mucize olarak bilinen olayların karıştııılması söz konusu olduğundan velilerin elinde zuhur eden hârikulâde olaylara keramet denilmesini uygun buluyoruz. Bunların dışında kalan doğrudan peygamberlerle ilişkili olsun veya olmasın ilahî amaçlı bütün hârikulâde olayları mucize olarak değerlendirmekteyiz.

Allah'ın kuluna umulmadık şekilde nimetler ihsan etmesi, maddî ve manevî afetlerden koruması şeklinde tezahür eden "maûnet" aslı itibariyle tabiat kanunlarıyla açıklanamayan bir şey değildir; dolayısıyla bunları hârikulâde bulmuyoruz. Zalim, kâfir ve azgın kişiler Cenâb-1 Allah tarafindan tedricî olarak felâkete sürüklenirken geçici olarak bazı imkân ve başarılar sağlayabilirler. Bu imkân ve başarılara "istidrâc" adı verilmiştir. Bunların da hârikulâde olduklarını kabul etmiyoruz. Ancak bazı eserlerde istidrâcda bulunan şahsın bir gözü kör olan bir kişinin gözünü açacağım derken diğer gözünün de kör olmasını istidrâc olarak değerlendirmişlerdir. Bu harikulâde bir durumdur. Ancak istidrâcda bulunanın lehine değil, aleyhine bir haldir. Allah'ın bu tür olaylarla, bu tür şahısların yalancı olduğunu işaret etmesi bakımından bu olayları mucize olarak kabul etmek daha uygun olur. Fakat bu olaylar istidrâcta bulunun kişinin değil, Allah'ın kişiden bağımsız olarak yarattığı bir mucizelerdir.

Mucize, hicrî üçüncü yüzyılın sonlarına doğru kullanılmaya başlanan bir kavramdır. Özellikle Eş‘arîler bu kavramı öylesine sert ve dar bir şekilde tanımlamışlardır ki, neredeyse bu tanıma tam olarak uyan bir örnek bulmak mümkün olmayacaktır. Biz Kur'an'da olağanüstü olduğu kabul edilen olaylardan hareket ederek ve bunları tamamen içine alacak şekilde mucizenin yeniden tanımlanması gerektiği kanaatindeyiz. Yaptığımız araştırma sonucunda amacı bakımından mucizelerin sekiz kısma ayrılabileceklerini söylemek mümkündür:

\section{1. İ‘lâm/Bildirim Mucizeleri}

Arapçada "i‘lâm", bildirmek anlamına gelmektedir. Biz bu terimi "Cenâb-1 Allah'ın Peygamberlerine nebî olduklarını bildirmesi” amacıyla, onlara gösterdiği mucizeler için kullanacağız.

Kur'an-1 Kerim'de sıkça vurgulandığı üzere peygamberler bizim gibi birer beşerdir. Beşer olarak biz, ne doğrudan ne de vasıtalı olarak Cenâb-1 Allah'tan vahiy alma imkânına sahip değiliz. Fakat bizim gibi beşer olan bazı zatlar peygamber

olduklarını ve Cenâb-1 Allah’tan vahiy aldıklarını söylüyorlar. Beșer olmaları 
açısından bakıldığında onların da vahiy almaması gerekirdi. Bununla birlikte Allah'ın taleplerini insanlara bildirmek istemesi bazı zevatın aracılık yapmalarını zorunlu kılar. Bu durum iki gerekliliği beraberinde getirir: Birinci olarak, peygamber olan zatın, kendisinin peygamber olduğunu bilmesi; ikinci olarak, peygamberin sair insanlara kendisinin peygamber olduğunu ispat eden bir delil sunması.

Bir zatın peygamber olduğunu muhataplarına ispat etmesi ne kadar önemli ise, kendisinin peygamber olduğunu bilmesi de en az o kadar önemlidir ve onun da peygamber olduğunu bilmesi için bazı delillere ihtiyacı vardır. Câhiz'in (ö. 255/869) vurguladığı gibi hiçbir kişi sadece kendi adaletine, kavminin kendisini temiz bir kişi olarak bilmesine, yalanının olmamasına güvenip peygamberlik iddiasında bulunamaz. ${ }^{7}$ Bir zata peygamber olduğu üç yolla bildirilmiş olabilir:

\subsection{Peygamber'in Kalbinde Zorunlu Bilginin Yaratılması Yoluyla}

Fahreddin er-Râzî’nin bu konudaki görüşü şöyledir: Yüce Allah peygamber olacak olan zata, kendisinin resûl olduğunu melek vasitasıyla bildirir. Peygamberinin kalbinde, gelen varlı̆̆ın doğru bir melek olup yalancı bir şeytan olmadığı kanaatini sağlayacak açık (bedihî) ve zarurî bir bilgi yaratır. Eğer peygamberde böyle bir mana hâsıl olmazsa, o zaman kendisine gelen şeyin Allah tarafından gönderilen bir melek olduğunu bilmesi mümkün olmaz; dolayısıyla konunun aslında bir şüphe meydana gelirse onunla ilişkili diğer konularda (fer') da şüphe meydana gelir. Bu sebeple Yüce Allah peygamberin kalbinde kendisine gelen varlığın doğru bir melek olduğuna dair zorunlu bir bilgi hâsıl eder. ${ }^{8}$

\subsection{Vahiy Yoluyla}

Bir zatın peygamber olduğunu bilmesi, başkalarına peygamber olduğunu ispat etmesinden daha önemlidir. Bize göre bir peygamber Yüce Allah ile irtibatını hangi yolla sağlıyorsa, başka bir ifade ile hangi yollarla vahiy alıyorsa, kendisinin peygamber olduğunu da bu yolla öğrenir. Kur'an'ın beyanına göre bir peygamber vahyi üç şekilde alır: Melek aracılığıyla, melek dışındaki başka bir şey aracılığıyla, aracısız olarak kalbe ilkâ yoluyla. ${ }^{9}$ Bunları şöyle açabiliriz:

a. Melek aracılığıyla: Yüce Allah vahyini çoğunlukla Cebrail vasitasıyla bildirdiği gibi, nebî olan zatın peygamber olduğunu da bu yolla bildirir. Bazen

7 Ebû Osman Amr b. Bahr b. Mahbûb el-Câhız, Hz. Muhammed'in Nübüvvetinin Delilleri (Hucecü'n-nübüvve), (metin-çeviri), çev. İbrahim Halil Erdoğan (Kayseri: Kimlik Yayınları, 2017), 105

${ }^{8}$ Râzî, el-Metâlibü'l- 'âliye, 8/86.

9 Yusuf Șevki Yavuz, "Vahiy", Türkiye Diyanet Vakfi İslâm Ansiklopedisi (İstanbul: TDV Yayınları, 2012), 42/ 440.

Turkish Academic Research Review - Türk Akademik Araştırmalar Dergisi 
peygamberin bu yolla resûl olduğunu bilmesi ile ilk vahye mazhar olması arasında bir zaman farkı olmaz. Hz. Muhammed'in, peygamber olduğunu daha çok Cebrail aracıllı̆̆ıla öğrendiğini söyleyebiliriz.

Cebrail vasıtasıyla vahiy üç şekilde gelmiştir: Cebrâil, bazen kendi aslî sûretinde görünerek, bazen görünmeden çan sesine veya arı vızıltısına benzer sesler aracılığıyla, bazen de insan şekline girerek vahyi getirirdi. ${ }^{10} \mathrm{~Hz}$. Peygamber'in nebî olduğunu bilmesi Cebrail'i ilk defa aslî keyfiyetiyle görmesiyle olmuştur. Hz. Peygamber, Cebrail'i asli keyfiyetiyle iki defa görmüştü. Bunlardan birincisi Hira dağında gerçekleşmiştir. ${ }^{11}$ Cebrail en yüksek ufukta iken sarkarak aşağı doğru inmiş, ikisi arasındaki mesafe iki yay arası kadar veya daha az kalmış bir halde iken Allah'ın vahyini bildirmiştir. ${ }^{12}$ Resûl-i Ekrem (sav), Cebrail'i aslî keyfiyetiyle ikinci kez “cennetü’l-me'vâ"nın yanında bulunan "sidretü'l-müntehâ"da görmüştür. ${ }^{13}$

İncillerde otuz yaşlarında iken Hz. Îsâ'nın Yahyâ tarafindan vaftiz edildiğinden, ${ }^{14}$ daha sonra Rûhulkudüs'ün onu çöle götürdüğünden ve çölde kırk gün, kırk gece oruç tuttuğundan söz edilir. İblîs onu iğvâya çalışmış fakat başarılı olamayınca peşini bırakmıştır. ${ }^{15}$ Bu bilgilerin doğru olması halinde Yüce Allah Hz. İsa'ya da, peygamber olduğunu Cebrail vasıtasıyla bildirmiş olmaktadır. Hz. İsa'nın kırk gün çölde kaldıktan sonra tebliğe başladığı ifade edilmektedir. ${ }^{16}$ Kur'an'da Hz. İsa'ya peygamberliğin verildiği zamandan bahsedilmez, ancak ona kitap verildiği ve mübarek kılındığı belirtilir. ${ }^{17}$

b. Melek dışındaki başka bir şey aracılığıyla: Cenab-ı Allah bazı nesnelerde veya insandaki duyma merkezinde sözünü duyurup yaratmasıyla peygamberle ilk olarak irtibata geçer ve o zat peygamber olduğunu anlar. Cenab-1 Allah'ın Hz. Mûsâ'yı peygamber olarak görevlendirmesi ve onun da kendisinin peygamber olduğunu bilmesi bu yolla olmuştur. Ateş görünümlü bir nesne vasıtasıyla Hz. Musa ile konuşarak onu nübüvvetle görevlendirmiş, sonra da nübüvvetini ispat için kendisine yed-i beyzâ ve âsa mucizelerini vermiştir. Hz. Musa bu görüşmede

\footnotetext{
10 Yavuz, "Vahiy", 42/441.

${ }^{11}$ Buhârî, "Ta'bîr", 1, "Bed' ü'l-halk"̣”, 7; Müslim, “Îmân”, 257, 258.

12 en-Necm 53/7-10.

13 en-Necm, 53/14-15.

${ }^{14}$ Luka $3 / 23$.

${ }_{15}$ Matta, 3/13-17, 4/1-11; Markos, 1/12-13; Luka, 4/1-13.

16 Ömer Faruk Harman, "Îsâ", Türkiye Diyanet Vakfi İslâm Ansiklopedisi (İstanbul: TDV Yayınları, 2000), 22/467.

17 el-Mâide 5/75; Meryem 19/30-31.
} 
peygamber olduğuna o kadar inanmıştı ki, Firavun'la olan problemlerini dahi Yüce Allah ile konuşmaya başlamıştır. ${ }^{18}$

c. Doğrudan kalbe ilkâ: Arada melek gibi bir elçi bulunmadan Yüce Allah resûlünün kalbine gizli bir işaretle ilâhî kelâmını bırakır. Bu tür vahiyde peygamber, ilâhî kelâmı uyanıkken ruhî bir tecrübe yaşayarak alırlar. ${ }^{19}$ Cenab-ı Allah bazı peygamberlere resûl olduğunu bu yolla bildirmiş olabilir. Meselâ İbrahim aleyhisselam babasına "Babacı̆̆ım! Doğrusu sana gelmeyen ilim bana geldi. O halde bana uy da, seni doğru bir yola ulaştırayım"20 sözü böyle bir durumu çağrıştırmaktadır.

Kur'an'da ayrı ayrı her peygamberin nebî olduğuna dair bir belge verildiği beyan edilmemiş olsa da, Nuh aleyhisselam'a böyle bir delil (beyyine) verildiği açıkça ifade edilmiştir. ${ }^{21}$ Taberî’ye (ö. 310/923) göre Nuh’a Rabbi tarafından verilen bu "beyyine", Allah tarafindan kendisine verilen bilgi, marifet ve beyandır. ${ }^{22} \mathrm{Bu}$ bilgi de ona Allah'ın kalbine ilkâ ettiği vahiy vasıtasıyla meydana gelmiştir.

\subsection{Mucize Yoluyla}

Bir nebî, peygamber olduğunu nasıl başka insanlara mucize yoluyla ispat ediyorsa, Cenâb-1 Allah da bazen resûl olarak görevlendirdiği zatın peygamber olduğuna inanması için ona bazı mucizeler göstermiştir. Cenâb-1 Allah'ın Hz. Musa'ya ateşin içinden seslenmesi, ${ }^{23}$ yed-i beyzâ, ${ }^{24}$ asanın yılana dönüşmesi ${ }^{25}$ bu tür mucizelerden sayılır. Hz. Peygamber'in Cebrail'i asli keyfiyetiyle görmesi ve peygamber olmadan önce taşların kendisine selam vermesi gibi hârikulâde olayları bu siniftan sayabiliriz.

Râzî’nin vurguladığı gibi peygamberler beşer olmakla beraber diğer insanlara karşı bazı üstünlükleri olan kimselerdi. ${ }^{26}$ Bu özellikleri sebebiyle Cenab-1 Allah onlarla vasitalı veya vasitasız irtibat kurabiliyor ve onlara kendilerinin peygamber olduğunu kabul ettirebiliyordu.

\footnotetext{
18 el-Kasas 28/29-33.

19 Elmalılı Muhammed Hamdi Yazır, Hak Dini Kur'an Dili (İstanbul: Eser Kitabevi, t.y.), $5 / 4255$.

${ }^{20}$ Meryem 19/43.

${ }^{21}$ Hûd 11/28.

${ }^{22}$ Ebû Ca'fer Muhammed b. Cerîr et-Taberî, Câmi 'u'l-beyân fi te'vîli'l-Kur'ân, nșr. Ahmed Muhammed Şakir (Kâhire: Müessesetü'r-Risâle, 1420/2000), 15/297.

23 Tâhâ 20/10; en-Neml 27/8-9.

24 el-A'râf 7/108; el-Kasas 29/30.

25 Tâhâ 20/19-21; en-Neml 27/10; el-Kasas 28/29-33.

${ }^{26}$ Râzî, el-Metâlibü'l-'âliye, 8/85.
}

Turkish Academic Research Review - Türk Akademik Araştırmalar Dergisi 
Ayrıca bütün peygamberlerin içlerinde hiçbir şüphe olmadan nübüvvet vazifesini sadakat ve salâbetle sürdürmeleri peygamber olduklarına dair kendilerine ikna edici bir delilin verildiğini gösterir. Peygamberliklerini ispat için kendilerine verilen mucizeler de bir taraftan kendilerinin de peygamber olduğunu gösteren deliller kabilindendir. Ancak önceden peygamber olduklarına inanmadan bunları göstermeleri pek mümkün görünmemektedir. Dolayısıyla önceden peygamber olduklarına inanmaları ve bu yönde kendilerine ikna edici deliller gösterilmesi gerekir.

\section{Hidayet/İrşad Mucizeleri}

Hidayet mucizeleri, inkârcıların talebi olsun veya olmasın peygamberlerin nübüvvetini ispat için gösterdikleri olağanüstü nitelikli olaylardır. Peygamberlerin nübüvvetini ispat için ortaya koydukları en önemli deliller bunlardır. Bunlara irşad mucizesi de denir.

"Hidayet mucizelerinin hedefi, peygamberlik iddiasında bulunan nebinin doğruluğunu ispat etmek ve insanları ikna etmek suretiyle inanmaya teşvik etmektir. Bu tür mucizeler, insanların yakîn ve kanaatleri üzerinde ektili olur; doğruları kabule meyilli, ön yargıdan uzak, akıllı, mantıklı ve sağduyu sahibi kimselere tesir ederler. Bunlara inanmayanların hemen helâk edilmeleri söz konusu olmayıp inkârcılara düşünme ve ibret almaları için mühlet verilir."”27

Hidayet mucizelerinin en temel özelliği tehaddî, bir başka ifade ile meydan okumadır. ${ }^{28}$ Bir peygamber ister inkârcıların talebi olmadan, ister onların talebi üzerine olsun nübüvvetini ispat için mucize gösterdiği zaman, aynı zamanda burada inkârcıların bu mucizenin benzerini getirmelerinin mümkün olmadığına ve bu konuda aciz kaldıklarına dair bir iddia ve itham da vardır. Hz. Peygamber'in meydan okuması Kur'an vasıtasıyla olmuştur. Kur'an'ın meydan okuması üç aşamada gerçekleşmiştir: Birinci aşamada inkârcılardan Kur'an'ın tamamına, ${ }^{29}$ ikinci

${ }^{27}$ Halil İbrahim Bulut, Nübüvvetin İspatında Mucize (Ankara: Araştırma Yayınları, 2016), 41. 28 Bulut, Nübüvvetin İspatında Mucize, 41; Yasin Ulutaş, İslâm Düşüncesinin Teşekkül Döneminde Mucize Anlayışları (Kahramanmaraş: Kahramanmaraş Sütçü İmam Üniversitesi, Sosyal Bilimler Enstitüsü, Doktora Tezi, 2018), 40.

29 et-Tûr 53/33-34; Bu âyetle Kur'an'ın son hali kadar değil, Tûr sûresinin indiği zamandaki miktarı kadar nazire getirmeleri istenmiștir. Genel olarak Tûr sûresinin genel 3. - 36. sıralarda nazil olduğu kabul edilir. Meselâ 34. sırada nazil olmuşsa âyette geçen "mislihî; onun benzeri" (et-Tûr 52/34) ifadesiyle o zamana kadar nazil olan sûreler kastedilmiștir. Yani 34 sûrenin benzerinin getirilmesi istenmiştir. el-İsrâ 17/88'de "De ki: Andolsun, bütün insanlar ve cinler, şu Kur'an'ın benzerini (yapıp) getirmek için toplansa, birbirlerine arka çıkıp yardım etseler, yine de onun benzerini getiremezler" buyurulmak suretiyle bu konudaki fiiî acziyetleri müşriklerin yüzlerine çarpılmıştır. İnkârcılardan Kur'an ve Tevrat'tan daha üstün bir kitap getirmeleri istenmesi de (el-Kasas 28/49) bu aşamadan sayılmalıdır. 
aşamada on suresine, ${ }^{30}$ üçüncü aşamada tek bir sûresine ${ }^{31}$ nazire getirmeleri istenmiştir. ${ }^{32}$ İnkârcılar Kur'an'ın en kısa sûresine nazîre getirebilmiş olsalardı, Hz. Peygamber'e karşı üstünlük sağlamış olacaklardı. Cahiz'in dediği gibi, “Eğer bir tek sûre ile muaraza edebilselerdi, davasını yalanlamış olacaklar, $O$ da onların yalanlarını tasdik etmiş olacaktı." ${ }^{33}$ Ancak onlar böyle kolay bir yol varken, bu yolu bırakıp kendilerinin ve çocuklarının ölümünü netice veren savaşlara kalkışmışlardır.

"Hidayet mucizeleri" denildiğinde her ne kadar insanın aklına hissî/kevnî mucizeler geliyorsa da, her zaman hidayet mucizelerinin yapısı itibariyle hissî mucizeler cinsinden olması gerekmez. Nitekim Hz. Peygamber'in en büyük mucizesi olan Kur'an, ${ }^{34}$ hissî değil, aklî bir mucizedir. H.İ. Bulut'un vurguladığı gibi "hidâyet mucizelerini hissî, aklî ve haberî olmak üzere üç şekilde değerlendirmek mümkündür." ${ }^{35}$ Ancak, geçmiş peygamberlerin gösterdikleri hidâyet mucizeleri genellikle hissî mucize cinsindendi. ${ }^{36}$

Hidayet mucizeleri Câhız’’n dikkat çektiği üzere genellikle toplumda revaçta olan konular cinsinden olurdu. Hz. Musa zamanında sihirbazlık revaçta olduğundan ona verilen mucizeler sihirbazları mağlup edecek cinsten olmuştu. Muhtemelen Hz. Musa sihirle ilgili olmayan bir mucize getirseydi, yine de halkın gönlü sihri ön planda tutar, fitneciler zayıf akıllı kimseleri sihir yoluyla etkilemeye devam ederlerdi. Cenâb-1 Allah bunlara meydan vermemek için Hz. Musa'ya sihirbazları mağlup eden mucizeler vermişti. Hz. İsa zamanında ise tıp bilimi revaç bulmuştu. Tabiplerin amacı hastaları tedavi etmek, kör olanları iyileştirmek, göz ağrılarına ilaç bulmak idi. Yüce Cenâb-1 Allah Hz. İsa'ya tıp alanında hekimlerin yapaktan aciz kaldıkları mucizeler verdi. Böylece hüner ile mucize birbirinden ayrıldı ve Hz. İsa'nın peygamber olduğu ortaya çıktı. Hz. Muhammed zamanında ise şiir ve güzel söz söylemek şöhret bulmuştu. Sözün güzelini en iyi onlar bilirdi. Allah da Hz.

\footnotetext{
${ }^{30}$ Hûd 11/13.

31 el-Bakara 2/23. Bakara Sûresi Medine'de nazil olmuştur. Anlaşıldığı kadarıyla Kur'an'ın meydan okuması Mekke dönemine münhasır kalmamış, Medine döneminde de devam etmiştir.

${ }^{32}$ Fahreddin er-Râzî Ebû Abdullâh Muhammed b. Ömer b. el-Hasan b. el-Hüseyn et-Teymî, Mefâtîhu'l-ġayb - et-Tefsîru'l-kebîr (Beyrut: Dâru İhyâi't-Türâsi'l-'Arabî, 1420), 2/349.

${ }^{33}$ Câhız, Hz. Muhammed'in Nübüvvetinin Delilleri, 116-117.

34 İmam Ebu Yusr Muhammed Pezdevi, Ehl-i Sünnet Akaidi, çev. Şerafeddin Gölcük (İstanbul: Kayıhan Yayınları, 1980), 138.

35 Bulut, Nübüvvetin İspatında Mucize, 41.

36 Bilal Atik, Kur'an'a Göre Değişmeyen Sünnetullah Olarak Mucize Olgusu (Ankara: Ankara Üniversitesi, Sosyal Bilimler Enstitüsü, Doktora Tezi, 2018), 91.
}

Turkish Academic Research Review - Türk Akademik Araştırmalar Dergisi 
Peygamber'in sözlerin en güzeli olan Kur'an mucizesiyle gönderdi ve inkârcılar onun benzerini getirmekten aciz kaldılar. ${ }^{37}$

Semûd kavmine peygamber olarak gönderilen Salih peygambere verilen dişi deve; ${ }^{38} \mathrm{~Hz}$. Musa'ya verilen yed-i beyzâ, ${ }^{39}$ asanın yılana dönüşmesi, ${ }^{40}$ asanın sihirbazların iplerini ve sopalarını yutması; ${ }^{41}$ Hz. İsâ'ye verilen çamurdan yaptığ kuş heykelinin canlanması, ${ }^{42}$ körü ve alaca hastasını iyileştirmesi, ${ }^{43}$ ölüleri diriltmesi, ${ }^{44}$ insanların evlerinde yedikleri ve biriktirdikleri şeyleri haber vermesi ${ }^{45}$ olayları Kur'an'da zikredilen hidayet mucizelerindendir.

Yed-i beyzâ ve asanın yılana dönüşmesi olayları bir taraftan i'lâm mucizesi iken diğer taraftan hidayet mucizesi olmaktadırlar. Zira bu iki mucizenin ilk uygulaması, Musa'ya ilk hitabın gerçekleştiği Tur'da olmuş, Musa bunları tecrübe ederek peygamber olduğuna dair kesin kanaati hasıl olmuştur. Dolayısıyla gaye bakımından tek bir mucize birkaç sınıfa girebilmektedir.

\section{Nusret Mucizeleri}

Bulut'un ifadesiyle nusret mucizeleri, "Müminlerin maddî ve manevî birtakım ihtiyaçlarını gidermeye yönelik olarak zuhur eden olağanüstü

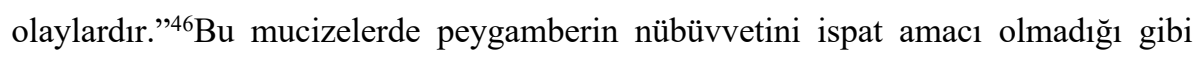
meydan okuma (tehaddî) özelliği de yoktur. Bununla birlikte olağanüstü olmaları ve bir peygamberin elinde zuhur etmeleri sebebiyle o peygamberin nübüvvetinin delili sayılırlar.

Nusret çoğunlukla müminlere yardım çerçevesinde peygamber de müminler kapsamında yer almaktadır. Hatta bazen peygambere yardım müminlere yardıma göre daha önde görülebilir. Bazen de müminlere yardımın daha çok öne çıktığı görülmektedir.

Kur'anda zikredilen başlıca nusret mucizeleri şunlardır:

\subsection{Nuh'un Gemisi}

37 Câhı, Hz. Muhammed'in Nübüvvetinin Delilleri, 126-127.

${ }^{38}$ eş-Şu'arâ 26/153.

39 el-A'râf 7/108; el-Kasas 29/30.

40 Tâhâ 20/19-21; en-Neml 27/10; el-Kasas 28/29-33.

${ }^{41}$ el-A'râf, 7/117; Tâhâ, 20/69; eș-Șu'arâ, 26/45.

42 Âl-i İmrân 3/49; el-Mâide 5/110.

43 Âl-i İmrân 3/49; el-Mâide 5/110.

44 Âl-i İmrân 3/49; el-Mâide 5/110.

45 Âl-i İmrân 3/49; el-Mâide 5/110.

${ }^{46}$ Bulut, Nübüvvetin İspatında Mucize, 42. 
Nuh peygamber, inkârlarına devam etmekle kalmayı ona eziyet etmeye başlayan kavmi hakkında"Rabbim yeryüzünde kâfirlerden kimseyi birakma"47 diye dua etmeye başlayınca, Yüce Allah "Gözetimimiz altında ve vahyimize göre gemiyi yap!"48 buyurdu. Geminin yapımı bittikten sonra Nuh'a gemiye her cins canlıdan (erkekli-dişili) birer çift ve kendisine iman edenleri almasını emretti. ${ }^{49}$ Sonra şiddetli yağmurlar yağdı, tufan oldu ve nihayet gemi Cûdî üzerinde karaya oturdu. ${ }^{50} \mathrm{Nuh}$ peygamber ve ona inananlar helak olmaktan kurtuldu. Geminin kendisi olağanüstü gibi görünmemekle birlikte, Allah'ın gözetimi altında yapılması sebebiyle vahye dayanan bir mucize sayılır. Gayesi bakımından ise bir nusret mucizesidir.

\subsection{Kızıldeniz'in Yarılması}

Firavun ve tabileri Hz. Musa'ya inanmayıp İsrailoğulları'nı olan zulümlerini arttırmaya başlayınca Yüce Allah kendisine bir gece gizlice İsrailoğulları'nı alıp Mısır'dan çıkmaları emretmişti. O da Allah'ın emrine uyarak İsrailoğulları'nı alıp Kızıldeniz'in kenarına kadar geldi. Firavun durumdan haberdar olup onları takibe başladı. Hz. Musa asasını vurmasıyla deniz ikiye yarıldı. Hz. Musa açılan yerden karşıya geçince Firavun da onu takip etti. Ancak Firavun ve ordusu sahile çıkamadan deniz üzerlerine kapaklandı, Firavun ve ordusu boğuldu, Hz. Musa ve İsrailoğulları ise kurtuldu. ${ }^{51} \mathrm{Bu}$ olay Firavun ve tabileri hakkında bir helâk, Hz. Musa ve İsrailoğulları için bir nusret mucizesi sayılır.

\subsection{Asayı Vurmasıyla Taştan On İki Adet Pınarın Fışkırmasıı}

Hz. Musa İsrailoğulları'nı Mısır'dan çıkardıktan sonra Tih çölünde ikamet etmeye başladılar. Ancak çölde yeteri kadar su yoktu. Kavmi Hz. Musa'dan su isteyince Allah kendisine "asanla taşa vur" diye emretti. Musa asasını taşa vurunca ayrı ayrı on iki pınar birden fışkırdı. ${ }^{52} \mathrm{Bu}$ da İsrailoğulları için bir nusret mucizesidir.

\subsection{Tevrat Nüshasının Yazılı Olarak Verilmesi}

Tevrat, Hz. Musa'ya parça parça değil, toptan yazılı olarak verilmiştir. ${ }^{53}$ Vahyin kendisi başlıbaşına bir mucize olmakla birlikte yazılı olarak verilmesi

\footnotetext{
${ }^{47}$ Nûh 71/26.

${ }^{48}$ Hûd $11 / 37$.

${ }^{49}$ Hûd 11/40.

${ }^{50}$ Hûd 11/44. Krș. Yazır, Hak Dini Kur'an Dili, 4/2779-27-83.

${ }^{51}$ Bk. Yunus 10/90; Tâhâ 20/77-78; eş-Şu'arâ 26/63-65; el-Kasas 28/40; ed-Duhân 44/24.

52 el-Bakara, 2/60; el-A'râf, 7/160.

53 el-A'râf $7 / 145$.
}

Turkish Academic Research Review - Türk Akademik Araştırmalar Dergisi 
muhataplarına karşı ikinci bir mucize kabilindendir. Bu da İsrailoğulları hakkında manevî yönü itibariyle bir nusret mucizesi sayıllır.

\section{5. İsrailoğulları'nın Bulutla Gölgelenmeleri, Kudret Helvası ve} Bıldırcın Eti Yemeleri

İsrailoğulları Hz. Musa'nın rehberliğinde Mısır'dan çıkıp Tih çölünde ikamet etmeye başladıklarında Yüce Allah bulutu bulutla üzerlerine gölge yapmış, onları kudret helvası ve bıldırcın etiyle doyurmuştur. ${ }^{54}$ Taberî kudret helvasının (menn) bir çeşit ballı ince ekmek olduğuna, semada kara benzer şekilde indirildiğine ve onu su ile karıştıııp içtiklerine; selvânın da bıldırcına benzer bir kuş olduğuna, rüzgârın onu semiz olarak getirdiğine dair çeşitli rivayetler nakletmektedir. ${ }^{55}$ Bütün bunlar İsrailoğulları için birer nusret mucizesi sayılır.

\section{6. Ölünün Dirilip Katilini Haber Vermesi}

Hz. Musa döneminde zengin ve yaşlı bir adam, mirasına konmak isteyen yeğeni tarafından öldürülmüş, ancak katilin kim olduğu bir türlü tespit edilememişti. İsrailoğulları durumu Hz. Musa'ya bildirdiler ve katilin bulunması için kendisinden yardım istediler. Yüce Allah bir inek kesmelerini ve bunun bir parçasıyla ölünün cesedine vurmalarını emretti. ${ }^{56}$ Netice itibariyle inek kesildi ${ }^{57}$ ve onun bir parçasılyla ölüye vuruldu. Ölü dirilip katilin kim olduğunu söyledi. ${ }^{58}$ Bu olay katilin bulunması hususunda İsrailoğulları için bir nusret mucizesi sayılır.

\subsection{Havarilere Semadan Sofra İndirilmesi}

Havariler Hz. İsa'ya gelip “Ey Meryem oğlu İsa! Rabbin bize gökten bir sofra indirebilir mi?" demişlerdi. İsa da, "Eğer mü’minler iseniz, Allah’a karşı gelmekten sakının” demişti. Onlar, "İstiyoruz ki ondan yiyelim, kalplerimiz yatışsın. Senin bize doğru söylediğini bilelim ve ona, (gözü ile) görmüşs şahitlerden olalım" demişlerdi. Meryem oğlu İsa, “Ey Allahım! Ey Rabbimiz! Bize gökten bir sofra indir ki; önce gelenlerimize (zamanımızdaki dindaşlarımıza) ve sonradan geleceklerimize bir bayram ve senden (gelen) bir mucize olsun. Bizi rizlklandır. Sen rızıklandıranların en hayırlısısın' dedi." ${ }^{59}$ Müfessirlerin çoğuna göre Hz. İsa'nın bu

54 el-Bakara, 2/57, el-A'râf, 7/160; Tâhâ, 20/80.

55 Taberî, Câmi 'u'l-beyân, 2/90-100.

56 el-Bakara 2/72-73.

57 İneğin kesilme seyri için bk. el-Bakara, 2/66-71.

58 Bk. Râzî, Mefâtîhu'l-ġayb, 3/544; Yazır, Hak Dini, 1/386-387; Hayreddin Karaman vd. Kur'an Yolu - Türkçe Meal ve Tefsir (Ankara: Diyanet İşleri Başkanlığı Yayınları, 2007), $1 / 142$.

59 el-Mâide 5/113-115. 
duasından sonra Yüce Allah gökten bir sofra indirilmiştir. ${ }^{60}$ Bu olay Havariler için bir nusret mucizesidir.

\section{4. İkram Mucizeleri}

İkram mucizesi kavramıyla biz, Cenâb-1 Allah'ın peygamberlerin maddi ve manevi ihtiyaçlarını karşılamak, onları desteklemek, taltif etmek ve çeşitli tehlikelerden korumak için onların elinde yarattığı olağanüstü olayları kastediyoruz. Başka bir ifade ile ikram mucizeleri peygamberlere yardım konusunda onlara has olan mucizelerdir.

Bazı araştırmacılar nusret ve ikram mucizelerini aynı sınıftan sayarken, ${ }^{61}$ bazıları ikram mucizesini ayrı bir mucize çeşidi olarak göstermektedir. ${ }^{62}$ İkram mucizeleri genel olarak nusret mucizeleri kapsamına dahil olmakla birlikte peygamberlere has olmaları bakımından farklı bir isimle anılmalarını normal karşı1lyoruz.

Bulut, nusret ve ikram mucizelerini ayırıp, nusret mucizelerini müminlere tahsis ettiği halde, ikram mucizesinin peygamberler ve bazı seçkin kulların imanlarını arttırmak ve onları taltif etmekle ilgili olduğunu ifade etmiştir. ${ }^{63}$ Biz ikram mucizesin konusu bakımından değil, muhatabı bakımından bir ayırıma tabi tutulmasının daha doğru olacağı kanaatindeyiz. Dolayısıyla konu ister maddî ve manevî ihtiyaçların karşılanması, ister imanın arttırılması olsun muhatap müminler ise buna nusret mucizesi, muhatap peygamber ise buna ikram mucizesi denmesi gerektiğini düşünüyoruz.

Kur'an-1 Kerim'de zikri geçen mucizelerin önemli bir kısmı ikram mucizesidir. Bunlar da en az hidayet mucizesi kadar olağanüstülük özelliklerine sahiptirler. Bir peygamberin elinde zuhur etmeleri sebebiyle aynı zamanda o peygamberin nübüvvet delili sayılırlar. Fakat hiçbiri o zatın nübüvvetini ispat maksadıyla zuhur etmemiştir. Bunlar tamamen Allah ile resûlü arasındaki özel

60 Taberî, Câmi 'u'l-beyân, 11/224-230; Beydâvî, Nâsırüddin Ebû Saîd Abdullah b. Ömer b. Muhammed eş-Şîrâzî, Envâru't-tenzîl ve esrârü't-te'vîl, thk. Muhammed Abdurrahman elMar'aşlî (Beyrut: Dâru İhyâi't-Türâsi'l-'Arabî, 1418), 2/150; Razî, Mefâtîhu'l-ġayb, 12/463; Zemahşerî, Ebü'l-Kāsım Mahmud b. Amr b. Ahmed, el-Keşşâf 'an hakâa 'ik-ı ġavâmiạı 't-te’ vîl (Beyrut: Dâru'l-Kitâbi'l-'Arabî, 1407), 1/693.

61 Atik, Kur'an'a Göre Mucize Olgusu, 93.

${ }^{62}$ Bulut, Nübüvvetin Íspatında Mucize, 43; Ulutaş, İslam Düşüncesinin Teşekkül Döneminde Mucize, 40. TDV İslâm Ansiklopedisi'nde "Mucize" maddesini yazan Bulut, ikram mucizesini ayrı bir kısım olarak ele almayıp nusret mucizesinin içinde düşünmüştür (Halil İbrahim Bulut, "Mûcize", Türkiye Divanet Vakfi İslâm Ansiklopedisi (İstanbul: TDV Yayınları, 2005), 30/350.

${ }^{63}$ Bulut, Nübüvvetin İspatında Mucize, 43.

Turkish Academic Research Review - Türk Akademik Araştırmalar Dergisi 
ilişkinin bir sonucu olarak ortaya çıkmıştır. Amacı da peygamberi maddeten veya manen takviye etmek, onları korumak ve bazı ihtiyaçlarını karşılamaktır. Kur'an'da zikri geçen ikram mucizelerini şu şekilde sıralayabiliriz:

\subsection{Ateşin Hâbil'in Kurbanını Yakması}

Hz. Âdem hem ilk insan, hem de eşinin ve çocuklarının peygamberiydi. Oğulları Hâbil ve Kâbil aynı kızı alma konusunda anlaşmazlı̆̆a düşmüşlerdi. Hz. Âdem, Kâbil'in haksız olduğunu söylüyordu. Ancak Kabil babasının sözünü dinlemek istemedi. Nihayet Hz. Âdem, kimin haklı olduğu konusunun açığa çıkması için iki kardeşin de kurban takdim etmelerini istedi. Öyle anlaşılıyor kimi haklı ise onun kurbanı Cenâb-ı Allah tarafından yakılacaktı. Kurbanlar sunuldu ve sonuçta Hâbil'in kurbanı kabul edilmişti. Ancak Kâbil kıskançlık yüzünden kardeşi Hâbil'i öldürdü. ${ }^{64}$ Kurban üzerine ateş gönderilip yakılması kimin haklı olduğunu ortaya çıkaran bir delil olmanın yanı sıra Hz. Âdem'e da manevî bir yardım sayılır. Medine'de Yahudiler'in Hz. Peygamber'e gelip kendisinden ateşin yakacağı bir kurban istemeleri ${ }^{65}$ bu tür mucizelerin sonraki peygamberlere de verildiğini göstermektedir. Bazı rivayetlere göre Hz. İsa'nın peygamberliği ile birlikte bu tür mucizeler kalkmıştır. ${ }^{66}$ Ateşin kabul edilen kurbanı yakması kendisinin haklılığının bilinmesi açısından Hz. Adem için bir ikram mucizesi sayılır.

\subsection{Parçalanmıș Kușların Dirilmesi}

Hz. İbrahim, Cenâb-ı Allah'ın ölüleri nasıl dirilttiğini merak ediyor, bu konuda imanı tam olmakla birlikte, kalbi tam olarak mutmain olmamış, bu sebeple ölüleri nasıl dirilttiğini Rabbinden talep etmişti. Allah da kendisine dört tane kuş alıp bunları parçalamasını, her parçasını bir dağın tepesine koymasını, sonra da bunları çağırmasını, bu takdirde hepsinin kendisine koşarak geleceklerini bildirdi. ${ }^{67}$

\subsection{Hz. İbrahim'in Aşırı Yaşı̆ı İken Çocuk Sahibi OIması}

Tevrat'ta yer alan rivayete göre Hz. İbrahim yüz, eşi Sâre doksan yaşına geldiği halde, ${ }^{68}$ henüz çocuk sahibi olmamışlardı. Nereden bakılırsa bakılsın bu

64 el-Mâide 5/27, 30. Konu hakkında geniş bilgi için bk. Ömer Faruk Harman, "Hâbil ve Kâbil", Türkiye Diyanet Vakfi İslâm Ansiklopedisi (İstanbul: Türkiye Diyanet Vakfi Yayınlar1, 1996), 14/376-378.

65 Âl-i İmrân 3/183.

${ }^{66}$ Hayrettin Karaman vd., Kur'ân-ı Kerim ve Açıklamalı Meâli (Ankara: Türkiye Diyanet Vakfi Yayınları, 2007),73.

67 el-Bakara 2/260.

68 Tekvin 16/17. 
yaştaki insanların ilk defa çocuk sahibi olmaları olağanüstü bir durumdur. Melekler azgın Lût kavmini helâk etmeye giderken Hz. İbrahim'e uğradılar, önce İshâk adlı oğlunun, ondan sonra da (torunu) Yakûb'un doğacağını haber verdiler. Bu haber karşısında Sâre o kadar şaşırmış̦tı ki, “Olacak şey değil!' Ben bir kocakarı, bu kocam da bir ihtiyar iken çocuk mu doğuracağım? Bu gerçekten şaşılacak bir şey!" demiş, Melekler onun bu sözüne, "Allah'ın takdirine mi şaşırıyorsun!" diyerek karşılık vermişlerdi. ${ }^{69}$ Nitekim haber verildiği gibi Sare'den İshâk dünyaya geldi. Meleklerin bu işi, “Allah'm takdiri”yle izah etmeleri olayın harika olduğunun bir delilidir.

\subsection{Hz. Yakûb’un Yusuf'un Kokusunu Alması ve Gözünün Açılması}

Hz. Yusuf'un büyük kardeşleri kıskançlık sebebiyle onu babasından koparmak istemişler, önce onu bir kuyuya atmışlar, sonra da onu kuyudan çıkaran kervancılara satmışlardı. Yusuf, kralın sarayında büyümüş ve maliye bakanı olmuştu. Kıtlık yıllarında kardeşleri hububat almak için birkaç kez Mısır'a gelmişler ve sonunda Yusuf onlara kendisini deșifre etmişti. Yusuf'un kaybolmasından sonra kardeşleri "Onu kurt yedi” deseler de, babası Yakub buna bir türlü inanmamış ve aşırı ağlamaktan ötürü gözleri görmez olmuştu. Yusuf kendisini deşifre edince kardeşlerine "Şu benim gömleğimi götürün de onu babamın yüzz̈̈ne koyun, (gözleri) görecek duruma gelir" ${ }^{970}$ demişti. Bazı rivayetlere göre Hz. Yakûb oğlundan kırk veya yetmiş yıl ayrı kalmış ve hüzün içinde yaşamış bulunuyordu. ${ }^{71}$ Kardeşleri Yusuf'un gömleğini getirip Yukûb da onu yüzüne sürünce gözleri açılmıştı. Bu olay hem Hz. Yusuf hem de Hz. Yakûb hakkında bir ikram mucizesi sayılır.

Diğer taraftan Yusuf'un kardeşleri Mısır'dan ayrılır ayrılmaz Hz. Yakûb, "Ben Yusuf'un kokusunu alyyorum"72 demeye başlamıştı. Mısır'daki gömleğin kokusunun Filistin'den hissedilmesi elbette olağanüstü bir olaydır. Ayrıca Hz. Yakûb'un kırk veya yetmiş yıldır hissetmediği kokuyu bu kadar zaman sonra hissetmesi de ayrı bir olağanüstülüktür. Bu da konuyla ilgili ikinci bir ikram mucizesidir.

\subsection{Hz. Yusuf'un Bazı Gaybî Bilgileri Bilmesi}

\footnotetext{
${ }^{69}$ Hûd 11/71-73; el-Hicr 15/54-55.

70 Yusuf 12/93.

71 Ömer Faruk Harman, "Ya'kûb", Türkiye Diyanet Vakfi İslâm Ansiklopedisi (İstanbul: TDV Yayınları, 2013), 43/275.

72 Yusuf 12/94.
}

Turkish Academic Research Review - Türk Akademik Araştırmalar Dergisi 
Bulunduğumuz yerde ister maddî ister manevî alanla ilgili olsun akıl ve duyular yoluyla hakkında bilgi sahibi olamadığım her alan gaybtır. Bu anlamda duvarın arka tarafı da gaybtır, melek ve cin gibi manevî alana ilişkin varlıklar da gayb alanıdır. Akıl ve duyu gibi bilgi vasıtalarını kullanmadan bir şey hakkında doğru bilgi vermek olağanüstü bir durumdur. Mucizelerin önemli bir kısmının gaybtan haber vermek şeklinde ortaya çıktığı görülmektedir. Bunun önde gelen örneklerinden biri de Hz. Yusuf'tur. Hz. Yusuf'un mucizeleri genellikle gelecekte meydana gelecek olan olayları bilmesi ve rüyaları gerçeğe uygun şekilde yorumlamasıdır. Kur'an'da Hz. Yusuf'la ilgili bu özellikleri taşıyan dört olaydan bahsedilir:

\subsubsection{Yemek Çeşitlerini Bilmesi}

Züleyha'nın tuzağı sonucunda Hz. Yusuf zindana atılınca, Mısır kralının başsâkîsi ve ekmekçisinin de orada olduğunu gördü, onlarla arkadaş oldu. Bunlar bir ara kendilerince garip sayılacak bazı rüyalar görmüşler ve Hz. Yusuf'tan rüyalarının tabir edilmesini istemişlerdi. Hz. Yusuf rüya tabirinin kendi marifeti olmadığını, bunu kendisine Allah'ın öğrettiğini söylemişti: "Size yedirilecek yemek gelmeden önce onun yorumunu (gelecek yemeğin ne olduğunu ve onun özelliğini) mutlaka size haber vereceğim. Bu, Rabbimin bana öğrettiklerindendir." 73

Hz. Yusuf'un gelecek olan yemeklerin isimlerini bilmesi mahiyeti itibariyle haberî bir mucize olmakla birlikte gayesi itibariyle daha çok bir ikram mucizesi olarak görünmektedir.

\subsection{2. Öldürülecek ve Serbest Bırakılacak Olan Kişileri Bilmesi}

Hz. Yusuf'la birlikte zindanda bulunan kralın başsâkîsi rüyasında şarap sıktığını, ekmekçisi ise başının üstünde bir ekmek taşıdığını ve kuşların bu ekmekten yediğini gördüğünü anlattı. Hz. Yusuf, başsâkînin rüyasını zindandan çıkarılacağı ve eskiden olduğu gibi efendisine şarap sunmaya devam edeceği; ekmekçinin ise idam edileceği, kuşların beynini yiyeceği şeklinde yorumladı. Sonuç Hz. Yusuf'un yorumladığı şekilde oldu. ${ }^{74}$ Bu olay da Hz. Yusuf'la ilgili bir ikram mucizesi olarak değerlendirilmelidir.

\subsubsection{Mısır Kralının Rüyasını Gerçeğe Uygun Şekilde Yorumlaması}

\footnotetext{
73 Yusuf 12/37.

${ }^{74}$ Yusuf 12/36-41. Krş. Tekvin 40/1-22.
} 
Mısır kralı rüyasında, yedi cılız ineğin yedi semiz ineği, yedi yeşil başağın da diğer kuru başakları yediğini görmüştü. Mısır'ın en ünlü rüya yorumcuları bu rüyanın karışık rüyalar (edgâsäu aḥlâm) cinsinden olduğunu, bu tür rüyaların yorumunu bilmediklerini söylediler. Uzun zaman önce zindandan çıkan başsâkî Hz. Yusuf'u hatırladı ve bu rüyayı onun yorumlayabileceğini söyledi. $^{75}$ Hemen zindana gidip durumu anlattı. Yusuf da rüyanın doğru yorumun yaptı. ${ }^{76}$ Bu yorum üzerine Mısır kralı Hz. Yusuf'un zindandan çıkarılmasını ister. $O$ ise önce kendisinin zindana atılması sebebi olan olayın hakikatinin ortaya çıkarılmasını ister. Daha sonra Mısır'a aziz (maliye bakanı) olur ve kıtlıkla ilgili bütün tedbirleri alır. Bu olay da Hz. Yusuf'un üçüncü haberî mucizesidir.

\subsubsection{Gömleğinin Babasının Gözünü Açacağını Bilmesi}

Hz. Yusuf Mısır'a üçüncü gelişlerinde kardeşlerine karşı kendisini deşifre edince, onlara "Şu benim gömleğimi götürün de babamın yüzüne koyun ki, gözleri açılsın ve bütün ailenizi bana getirin" ${ }^{77}$ demişti. Bu ifadeye göre Hz. Yusuf, gömleğinin babasının gözleri üstüne konulmasıyla açılacağını biliyordu. Bu da onun dördüncü haberî mucizesidir.

4.6.Hz. Musa'nın Allah'ı Görmek İstemesi Üzerine Dağın Parçalanması

Konuyla ilgili olarak sadece ilgili âyetin mealini vermekle yetineceğiz: “Musa, belirlediğimiz yere gelip Rabbi de ona konuşunca, 'Rabbim! Bana (kendini) göster, sana bakayım' dedi. Allah da, 'Beni (dünyada) katiyen göremezsin. Fakat (şu) dăga bak, ĕger o yerinde durursa sen de beni görebilirsin.' dedi. Rabbi dă̆a tecelli edince onu darmadă̆ın ediverdi. Musa da baygın düştü. Ayılınca, 'Seni eksikliklerden uzak tutarım Allah'ım! Sana tevbe ettim. Ben inananların ilkiyim' dedi."78 Dağın darmadağın olması mahiyeti itibariyle hissî, gayesi itibariyle bir ikram mucizesidir.

\subsection{Hz. Davûd ve Hz. Süleyman'a Verilen Mucizeler}

Kur'an-1 Kerim'de dağların ve kuşların Davud'la birlikte Allah'1 tesbih ettikleri $^{79}$ ve kendisine zırh yapma sanatının öğretildiği ${ }^{80}$ belirtilmiştir. Hz. Süleyman'la ilgili olarak da rüzgârın emrine verildiği ${ }^{81}$ bakırın kendisi için su gibi

\footnotetext{
${ }^{75}$ Yusuf 12/43-46.

${ }^{76}$ Yusuf 12/47-49. Krș. Tekvîn, 41/1-8.

77 Yusuf 12/93.

${ }^{78}$ el-A'râf $7 / 143$.

79 el-Enbiyâ 21/79; Sebe' 34/10.

80 el-Enbiyâ 21/80; Sebe' 34/10.

81 el-Enbiyâ, 21/81; Sebe' 34/12.
}

Turkish Academic Research Review - Türk Akademik Araştırmalar Dergisi 
akıtıldığ $1,{ }^{82}$ cinlerin emrinde çalıştığ ${ }^{83}$ kendisine kuş dilinin öğretildiği ${ }^{84}$ ifade edilmiştir. Bütün bu olayların olağanüstü özelliğe sahip birer mucize olup olmadıkları ihtilaflıdır. Klasik müfessirlerin çoğu bunları mucize olarak görmüşler, son asırda yazılan tefsirlerde ise genellikle bu olayların olağanüstü nitelikte olmadıkları, Allah'ın kendilerine verdiği özel imkân ve yetkinlikler sayesinde bunlara sahip oldukları belirtilmektedir. Eğer bu olaylar olağanüstü özelliklere sahip birer mucize olarak kabul edilirse tamamı gayesi bakımından ikram mucizesi sayılır.

\subsection{Hz. Zekeriyya'ya Verilen Mucizeler}

Hz. Zekeriyya bir hayli yaşlanmış olmasına rağmen henüz çocuk sahibi olamamıştı. Oysa büyük bir iştiyakla çocuk istiyordu. İleride kavminin haktan sapmasından korkuyor, yerine halef olarak bırakacağı çocuğun kavmine önderlik edeceğini umuyordu. Bir melek vasıtasıyla Yüce Allah yakında kendisinin Yahya isminde bir çocuğunun olacağını müjdeledi. Hz. Zekeriyya, kendisinin çok yaşlı, eşinin doğurgan olmadığını düşünerek “Benim nasıl çocuğum olur?” dedi. Melek ise Allah'ın, "Bu benim için çok kolay bir iştir. Daha önce seni yoktan var eden ben değil miyim?” buyurduğunu ona nakletti. Zekeriyyâ da “Rabbim! Öyleyse bana çocuk sahibi olacağıma dair bir alâmet göster!" talebinde bulundu. Bunun üzerine melek, "Senin istediğin alâmet üç gün boyunca insanlarla konuşamayacak olmandır" dedi. ${ }^{85}$ Zekeriyya peygamberin ve eşinin her ikisi de aşırı yaşlı olmakla birlikte çocuklarının olması Allah'ın kendilerine ihsan ettiği bir ikram mucizesidir.

\subsection{Hz. İsa'ya İlişskin Bazı Mucizeler}

Yüce Allah Hz. İsa'yı ve annesini mucize kıldığın ${ }^{86}$ beyan etmiştir. $\mathrm{Bu}$ ikisinin mucize olması Hz. Meryem'in herhangi bir erkekle teması olmadan hamile kalması ve İsa'nın da babasız dünyaya gelmesindendir. ${ }^{87}$ Doğduktan sonra $\mathrm{Hz}$. İsa'nın beşikte iken konuşması de ikinci bir mucizedir. ${ }^{88} \mathrm{Bu}$ ikisi Hz. İsa hakkında birer nusret mucizesidir.

${ }^{82}$ Sebe' 34/12.

${ }^{83}$ Sebe' 34/12-13.

84 en-Neml 27/16.

${ }^{85}$ Âl-i İmrân 3/38-41; Meryem 19/2-11; el-Enbiyâ 21/89-90.

86 el-Mü'minûn 23/50; Meryem 19/20-21.

87 Bk. Âl-i İmrân 3/39, 45; en-Nisâ 4/171; Meryem 19/16-22; el-Enbiyâ 21/91; et-Tahrîm 66/12.

${ }^{88}$ Meryem, 19/27-30. 
Hz. İsa'nın Allah tarafından kendisine yükseltildiğini ifade eden ayetler ${ }^{89}$ müfessirler tarafindan genellikle göğe yükseltildiği şeklinde anlaşılmıştır. ${ }^{90}$ Böyle olması halinde bu olay da bir ikram mucizesi sayılır.

\subsection{Hz. Peygamber'in İsra Mucizesi}

İsrâ, gece yürüyüşü demektir. Kur'an'da Hz. Peygamber'in bir gece Allah tarafindan Mescid-i Haram'dan Mescid-i Aksâ'ya götürüldüğü belirtilmiştir. ${ }^{91}$ Klasik tefsirlerde Mescid-i Aksa'nın genellikle Kudüs'teki Beyt-i Makdis olduğu kabul edilmiştir.92 Kur'an'da miractan söz edilmez. Hadislerde isrânın devamı olarak miractan bahsedilir. Başta Buhârî ve Müslim olmak üzere birçok hadis kaynağında geçtiği üzere Hz. Peygamber Mescid-i Aksa'dan göğe yükseltilmiş, göğün çeşitle katlarında farklı peygamberlerle görüşmüş, semada Cenâb-1 Allah'ın vahyine mazhar olduktan sonra aynı gece geri dönmüştür. ${ }^{93}$

\section{5. İsmet/Koruma Mucizeleri}

Yüce Allah,“Allah, seni insanlardan korur."94 buyurarak Hz. Peygamber’e kendisini düşmanlarından koruyacağını vadetmiştir. Fiili durumun da böyle olduğu görülmektedir. Hz. Peygamber müteaddit defalar düşmanlarının saldırısına uğradığı halde bazen tabiat kanunlarına uygun, bazen de olağanüstü bir şekilde her seferinde düşmanlarından kurtulmuştur. ${ }^{95}$

İsmet mucizesinden ilk söz eden zat Mâtürîdî’dir (ö. 333/944). Mâtürîdî, Hz. Muhammed'in peygamberliğini ispat eden delilleri beş kısma ayırır ve “dördüncüsünün muhalifler kendisine zarar vermeye çalıştığı halde hazırladıkları bütün tuzaklardan kurtulması ve Allah'ın himayesine mazhar olmasıdır"96 der.

\footnotetext{
89 Âl-i İmrân 3/55; en-Nisa 4/157-158.

${ }^{90}$ Ebû Zekeriyya Yahya b. Ziyâd b. Manzûr el-Ferrâ, Me 'âni'l-Kur'ân, thk. Ahmed Yusuf enNecâtî vd. (Misır: Dâru'l-Misriyye, 1955), 1/219; Semerkandî, Bahru'l-'ulûm, Ebü’l-Leys Nasr b. Muhammed b. Ahmed b. İbrahim (Beyrut: 1413/1993), 1/218; Beydâvî, Envârü'ttenzîl, 2/19; Râzî, Mefâtîhu 'l-ġayb, 8/237, 11/260.

91 el-İsrâ $17 / 1$.

92 Ebû Mansûr Muhammed b. Muhammed b. Mahmûd el-Mâtürîdî, Te 'vîlâtü Ehli's-Sünne, thk. Mecdî Bâselîm (Beyrut: Dâru'l-Kütübi'l-İlmiyye, 1426/2005), 7/3; Semerkandî, Bahru'l'ulûm, 2/299; Ebü'l-Hasan Ali b. Muhammed b. Muhammed el-Mâverdî, en-Nüket ve'l'uyûn. Beyrut: Dâru'l-Kütübi'l-'İlmiyye, t.y.), 2/226; Zemahșerî, el-Keșșâf, 2/647; Râzî, Mefâtîhu'l-ġayb, 20/292; Beydâvî, Envârü’t-tenzîl, 3/247; Yazır, Hak Dini Kur'an Dili, 5/3144-3153.

93 Bk. Salih Sabri Yavuz, "Mi'rac", Türkiye Diyanet Vakfi İslâm Ansiklopedisi (İstanbul: 2005), 30/132-135.

94 el-Mâide, 5/67.

${ }^{95}$ Genis bilgi için bk. Ali Bakkal, “Hz. Peygamber'in Düşmanlarından Korunması”, Diyanet İlmî Dergi 56 (2020), 493-522.

96 Mustafa Saim Yeprem, Mâtürîdî'nin Akîde Risâlesi ve Serhi (Ankara: Türkiye Diyanet Vakfi Yayınları, 2011), 29.
}

Turkish Academic Research Review - Türk Akademik Araştırmalar Dergisi https://dergipark.org.tr/tr/pub/tarr 
Mu'tezile imamlarından Kâdî Abdülcebbâr (ö. 415/1025) da Hz. Peygamber'in Allah tarafindan korunmasını, onun mucizeleri arasında sayar. ${ }^{97} \mathrm{Biz}$ de peygamberlerin korunması amacına matuf olarak vaki olan harikulâde olayları "İsmet Mucizesi” olarak adlandırmayı uygun bulduk. Aslında bu mucizeler ikram mucizelerinin özel bir kısmını teşkil etmektedirler.

Koruma mucizeleri sadece Hz. Peygamber'e mahsus olmayı zaman zaman geçmiş peygamberlerin ve kutsal mekânların korunması şeklinde de gerçekleşmiştir. Kur'an'da zikri geçen ismet mucizelerini şöyle sıralayabiliriz:

\subsection{Ateşin Hz. İbrahim’i Yakmaması}

Hz. İbrahim, putları kırdığı için Nemrut tarafından ateşe atılmış, ancak Cenab-1 Allah ateşe, “Ey ateş, İbrâhim'e karşı serinlik ve esenlik ol!"98 diye emredince ateş İbrahim'i yakmamıştı. ${ }^{99} \mathrm{Bu}$ mucize sayesinde Hz. İbrahim ölmekten kurtulmuştur.

\subsection{Bıçağın Hz. İsmail’i Kesmemesi ve Gökten Kurban İnmesi}

İsmail koşma çağına geldiğinde Cenab-1 Allah rüyasında Hz. İbrahim’e İsmail'i kurban etmesini emretmişti. Ancak bu, Hz. İbrahim'i imtihan etmek içindi, maksat Hz. İsmail'in kurban edilmesi değildi. Hz. İbrahim Allah'ın emrini yerine getirmek üzere bıçağı Hz. İsmail’in boğazına salladığında bıçak İsmail’i kesmedi, ayrıca İsmail'e bedel gökten bir kurban indirildi. ${ }^{100} \mathrm{Bu}$ durum hem Hz. İbrahim, hem de Hz. İsmail hakkında bir ismet mucizesi sayılır.

\subsection{Hz. Eyyûb'un İyileşmesi}

Hz. Eyyûb şiddetli bir şekilde hastalanmış, sabır sahibi bir peygamber olmakla birlikte sonuçta, "Başıma bu dert geldi, Sen, merhametlilerin en merhametlisisin" diye Allah'a dua etmek mecburiyetinde kalmıştı. Yüce Allah onun duasına, “Bunun üzerine biz, tarafimızdan bir rahmet ve kulluk edenler için bir hatıra olmak üzere onun duasını kabul ettik; kendisinde dert ve sıkıntı olarak ne varsa giderdik ve ona aile efradını, ayrıca bunlarla birlikte bir mislini daha verdik." ${ }^{101}$ diyerek karşılık

\footnotetext{
${ }^{97}$ Kādî Abdülcebbâr b. Ahmed, Teșbîtü delâ'ili'n-nübüvve (Mucizelerle Hz. Peygamber'in Hayatı), çev. M. Şerif Eroğlu \& Ömer Aydın (İstanbul: Türkiye Yazma Eserler Başkanlığı, 2017), 450-452.

98 el-Enbiyâ 21/69.

99 Taberî, Câmi 'u’l-beyân, 18/466.

100 es-Sâffât 37/102-108.

101 el-Enbiyâ 21/84.
} 
vermiş ve onu iyileşmişti. Hz. Eyyûb'un ağır hastalıklardan iyileşmesi geniş anlamda bir ikram mucizesi, dar anlamda ismet mucizesi sayılır.

\subsection{Bir Kişinin Hz. İsa'ya Benzetilmesi}

"Ve 'Biz Allah'ın peygamberi Meryem oğlu İsa Mesih'i öldürdük' demelerinden dolay kalplerini mühürledik. Oysa onu öldürmediler ve asmadılar. Fakat onlara öyle gibi gösterildi. Onun hakkında anlaşmazlı̆ga düşenler, bu konuda kesin bir şüphe içindedirler. O hususta hiçbir bilgileri yoktur. Sadece zanna uyuyorlar. Onu kesin olarak öldürmediler." 102 âyetinin açık ifadesine göre Yahudiler tarafından çarmıha gerilip asılan Hz. İsa değil, ona benzetilen bir kişidir. Bir kişinin İsa'ya benzetilmesi bir mucizedir.

Bir rivayete göre Yahudiler Hz. İsa'yı öldürmek için bir araya gelmişler, Allah da İsa'ya kendisini göğe yükselteceğini haber vermişti. Bunun üzerine Hz. İsa arkadaşlarına, "hanginiz benim suretime çevrilip öldürülmeye, asılıp Cennete girmeye razı olur?" diye sordu. Arkadaşlarından biri ayağa kalktı, Allah onu İsa suretine çevirdi. Sonra bu zat İsa zannedilerek çarmıha gerildi ve öldürüldü. ${ }^{103} \mathrm{~Hz}$. İsa'ya benzetilen kişi hakkında farklı rivayetler vardır. ${ }^{104}$ Müfessirlerin kahir ekseriyetine göre çarmıha gerilen kişi, Allah'ın Hz. İsa'ya benzettiği bu kişidir. Bu da Hz. İsa'yı koruma mucizelerinden biridir.

\subsection{Ashab-ı Kehf'in Korunması}

Ashab-1 Kehf olayı bir yönüyle inanan gençlerin korunmasına diğer yönüyle yeniden dirilişin hak olduğuna delâlet eden bir mucizedir.

\subsection{Fil Olayında Kâbe'nin Korunması}

Yemen Valisi Ebrehe Arabistan'1 Hıristiyanlaştırmak istiyordu. Arapların dini maksatla Kâbe'yi ziyaret ettiklerini görünce Sana'da ondan daha güzel bir kilise yaptırdı. Çeşitli bölgelere propagandacılar göndererek halkı bu kiliseyi ziyaret

102 en-Nisâ 4/157.

103 Taberî, Câimi 'u'l-beyân, 9/368, 370, 372; İbn Ebî Hâtim, Ebû Muhammed Abdurrahman b. Muhammed b. İdris b. el-Münzir, Tefsîru'l-Kur'âni'l- 'Azîm, thk. Es'ad Muhammed etTayyib (Suudi Arabistan: Mektebetü Nizâr Mustafa el-Bâz, 1419), 4/111; Zemahşerî, Keşşâff, $1 / 587$.

104 Taberî, Câimi 'u’l-beyân, 9/367-377; İbn Ebî Hâtim, Tefsîru'l-Kur'âni'l- 'Ażîm, 4/111; İbn 'Atıyye, Ebû Muhammed Abdülhak b. Gâlib b. Abdirrahman b. Temâm b. 'Atiyye elEndelûsî, el-Muharreru'l-vecîz fì tefsîri'l-Kitâbi'l-'Azîz, thk. Abdüsselâm Abdüşşâfî Muhammed (Beyrut: Dâru'l-Kütübi'l-'Illmiyye, 1422), 2/133; Zemahşerî, Keşşâf, 1/587; Râzî, Mefâtîhu'l-gayb, 11/260-262; Beydavî, Envâru't-tenzîl, 2/107; Yazır, Hak Dini Kur'an Dili, 3/1517; Ömer Faruk Harman, "Issâ", Türkiye Diyanet Vakfi İslâm Ansiklopedisi (İstanbul: TDV Yayınları, 2000), 22/470.

Turkish Academic Research Review - Türk Akademik Araştırmalar Dergisi 
etmeye çağırdı. Fakat Araplar Kâbe'yi ziyaret etmeye devam ettiler. Üstelik Kinâne kabilesine mensup bir Arap, Kâbe'nin yerine geçirilmek istenen bu kiliseye giderek pisledi. Bunun üzerine Ebrehe, Hıristiyanlı̆̆ın yayılmasına engel teşkil ettiğini düşündüğü Kâbe'yi yıkmak üzere içinde Mahmûd adlı bir filin de bulunduğu ordusuyla Mekke üzerine yürüdü. Mekke yakınlarındaki Mugammes denilen mevkie gelince burada ordugâhını kurdu. Mekke reisi Abdülmuttalib, kendilerini Ebrehe'yi yenecek güçte görmediğinden halktan şehir dışına çıkmalarını istedi ve beytini koruması için Allah'a dua etti. Ebrehe Mekke üzerine hücum emrini verdiği zaman Mahmûd'u yerinden kımıldatamadılar. Bu esnada Yüce Allah'ın sürü halinde gönderdiği kuşlar Ebrehe ordusunun üzerine balçıktan pişirilmiş taşlar atarak onları yenilmiş yaprakları haline getirdi. ${ }^{105}$

\subsection{Savaşlarda Meleklerin Müslümanlara Yardımı}

Kur'an'da Bedir, Uhud, Hendek ve Huneyn savaşlarında Allah'ın melekler vasıtasıyla görünmeyen ordular indirerek Müslümanları desteklediği belirtilmektedir. ${ }^{106}$ Tefsirlerde bu yardımın mucizevî şekilde gerçekleştiği anlatılmaktadır. Savaşlarda Müslümanların meleklerle desteklenmelerini onların korunmasına yönelik mucizeler olduğunu söyleyebiliriz.

\subsection{Bedir Savaşında Düşmana Atılan Bir Avuç Kumun Düşman} Askerlerinin Gözlerine Gitmesi

Bedir Savaşı münasebetiyle Yüce Allah şöyle buyurmaktadır: "(Savaşta) onlarl siz öldürmediniz, fakat Allah onları öldürdü. Attı̆gn zaman da sen atmadın, fakat Allah attı..." ${ }^{107} \mathrm{Bu}$ âyetle ilgili olarak şöyle bir hadis rivayet edilmiştir: Hz. Peygamber Bedir Savaşı'nda yerden bir avuç toprak ve küçük taşları alıp "Şâheti'lvücûh: Yüzleri kara olsun" diyerek düşman ordusuna doğru atmış. Atılan bir avuç kum binlerce avuç kum olarak düşmanın gözlerine gitmiş ve düşman da kaçmış. ${ }^{108}$ Âyet bu rivayet çerçevesinde anlaşıldığı zaman, olay Müslümanları korumak için meydana gelen bir mucize olarak değerlendirilebilir.

\section{6. İkaz/Uyarı Mucizeleri}

Yüce Allah zaman zaman peygamberlerine vazifelerini yapmaları, müminlerin itaat üzere olmaları, inkârcıların ise küfürlerinde ısrarlı olmamaları

105 el-Fîl 105/1-5. Geniş bilgi için bk. Mustafa Fayda, "Fil Vak'ası", Türkiye Diyanet Vakfi İslâm Ansiklopedisi (İstanbul: TDV Yayınları, 1996), 13/70-71.

106 Bk. el-Enfâl 8/9-10; Âl-i İmrân 3/122-123; et-Tevbe 9/26.

107 el-Enfâl 8/17.

108 Ahmed b. Hanbel, el-Müsned, 1/303. 
hususunda bazen olağanüstü bir olay vasıtasıyla onlara ikazda bulunmuştur. Bu tür mucizelere iz ikaz mucizesi demeyi uygun bulduk. Kur'an'da konuyla ilgili olarak zikredilen bazı olaylar şöyledir:

\section{1. Peygamberi İkaz}

Hz. Yûnus, Ninova halkına peygamber olarak gönderilmişti. Halkını Allah yoluna davet için çok çabaladı. Fakat bir ara onlara kızıp uzaklaşmak istedi. ${ }^{109}$ Yükü fazla olan bir gemiye bindi. Geminin batmaması için birilerinin denize atlaması gerekiyordu. Hiç kimse kendi rızasıyla atlamak istemediği için kur'a çekildi ve kur'a Yunus Peygamber'e çıktı. Denize atıldığında büyük bir balık onu yuttu. ${ }^{110}$ "Senden başka hiçbir ilâh yoktur. Seni eksikliklerden uzak tutarım. Ben gerçekten (nefsime) zulmedenlerden oldum"111 diye dua ederek Allah'tan affinı istedi. Duası kabul edildi ve balık kendisini sağ olarak sahile attı. Kendisine gölge yapması için yanında kabak türü bir bitki olan geniş yapraklı yaktîn bitkisi yaratıldı. ${ }^{112}$ Yunus peygamberin başına bu olayın gelmesi kendisi hakkında bir ikaz mucizesi sayılır.

\subsection{Müminleri İkaz}

Bazen Yüce Allah iman ettiklerini söyledikleri halde sözlerinde durmamaları sebebiyle mucizelerle müminleri ikaz etmiştir.

İsrailoğulları buzağıya tapmaya başladıktan sonra Cenab-1 Allah onları affetmiş; sözlerini tutmaları için Sina Dağı'nı yerinden kopararak üzerlerine kaldırmıştır. ${ }^{13}$ Müfessirler çoğunlukla dağın gerçekten İsrailoğulları’nın üzerine kaldırıldığı şeklinde anlamışlardır. ${ }^{114} \mathrm{Bu}$ durumda olay ikaz mucizesi sayılır.

Hz. Musa Tûr dağına gittiğinde Sâmirî diye bir adam bir buzağı heykeli yapıp İsrailoğulları'nı ona tapmaya ikna ettiği zaman geri döndüğünde tekrar onları Allah'ı inanmaya ve ibadet etmeye davet etti. Ancak onlar, "Biz Allah'ı açıkça görmedikçe sana inanmayacağız" demişlerdi. Bunun üzerine Yüce Allah'ın gönderdiği yıldırım onları çarpmışt.1. ${ }^{15}$ Âyette geçen "Sonra ölümünüzün ardından sizi dirilttik ki şükredesiniz."116 ifadesini bazı müfessirler İsrailoğulları'nın gerçekten ölüp tekrar diriltildikleri, bazıları da İsrailoğulları'nın bayıldığı şeklinde

\footnotetext{
109 el-Enbiyâ 21/87.

110 es-Sâffât 37/140-142.

111 el-Enbiyâ 21/87-88; es-Sâffât 37/143-144.

112 es-Sâffât 37/145-146; el-Kalem 68/49-50.

113 el-Bakara 2/63; en-Nisâ 4/154; el-A'râf 7/171.

114 Râzî, Mefâtîhu'l-gayb, 3/538; Beydâvî, Envârü't-tenzîl, 1/85; Yazır, Hak Dini, 1/377; Karaman vd, Kur'an Yolu, 1/137.

115 el-Bakara 2/55-56; en-Nisâ 4/153.

116 el-Bakara 2/55-56.
}

Turkish Academic Research Review - Türk Akademik Araştırmalar Dergisi https://dergipark.org.tr/tr/pub/tarr 
yorumlamışlardır. ${ }^{117}$ Ölüp dirilme olayı gerçekleşmemiş olsa dahi yoğun şekilde meydana gelen yıldırım olaylarını Allah'ın İsrailoğulları'nı uyarısı şeklinde kabul etmek gerekir.

\section{7. İnzar/Korkutma Mucizeleri}

İnzâr korkutma anlamına gelmektedir. "Biz mucizeleri sırf korkutmak için göndeririz"118 âyetinden açıkça anlaşılacağı üzere mucizelerin amaçlarından birisi de inkârcıları korkutup daha iyi düşünmelerini ve sonuçta iman etmelerini sağlamaktır. Yüce Allah kendisine inanmayan kavimleri peygamberleri vasitasıyla müteaddit defalar uyarmaktadır. Buna rağmen inanmamakta ssrar edip bir de gönderdiği peygambere eziyet etmeye başlayınca Yüce Allah son sözünü söyleyerek bundan sonra inanmamaları halinde kendilerini yok edecek bir azabın geleceğini, ya da peygamberi eliyle bir mucize göstererek buna rağmen inanmazlarsa helâk edileceklerini bildirilmektedir. Başka bir ifadeyle inzar mucizelerinden sonra hala münkirler inanmamaya devam edecekse artık helak edileceklerdir. İsyankâr kavimlerin kendileriyle korkutuldukları bu olaylara inzar mucizesi demeyi uygun bulduk. Kur'an'daki buna dair bazı örnekler şöyledir:

\subsection{Nuh'un Gemisi}

Yukarıda Nuh'un gemisini müminlerin ona binip ölümden kurtulmaları sebebiyle nusret mucizesi olarak değerlendirmiştir. Konuya inkârcılar açısından bakıldığında bu bir inzar mucizesi olmaktadır. İnkârcılar küfürlerinde inad edip "Ĕger doğrulardan isen, kendisiyle bizi tehdit ettiğin (azabl) getir!" 19 deyince kavminin yaptığı ezalara dayanamayan Nuh peygamber, "Rabbim yeryüzünde kâfirlerden kimseyi birakma"120 diyerek hepsinin helakini istedi. Allah da "Gözetimimiz altında ve vahyimize göre gemiyi yap!"121 buyurdu. Dolayısıyla gemi Nuh kavmi için bir inzâr mucizesi sayılır.

\subsection{Vadilere Doğru Yayılan Bulut}

Yüce Allah Âd kavmine Hûd'u peygamber olarak göndermiş̧i. Âyetin ifadesiyle Hûd onlara, “Ancak Allah'a ibadet edin, çünkü ben sizin adinıza büyük bir günün azabından korkuyorum"122 diye onları uyarmıştı. Onlar ise "Doğru

117 Razî, Mefâtîhu'l-ġayb, 3/521; Beydavî, Envârü 't-tenzîl, 1/81. Yazır, Hak Dini, 1/357; Karaman ve dŏr., Kur'an Yolu, 1/125.

118 el-İsrâ $17 / 59$.

119 Hûd 11/32.

${ }^{120}$ Nûh $71 / 26$.

121 Hûd 11/37.

122 el-Ahkâf 46/21. 
söyleyenlerden isen bezi tehdit ettiğin şeyi başımıza getir!" diyerek iman etmemekte direndiler. Yüce Allah onlart inzar mucizesi olarak bir bulut gönderdi. "O azabı vadilerine doğru yayllan bir bulut olarak gördüklerinde, 'Bu, bize yağmur getiren bir buluttur' dediler. Hûd, 'Hayır, o sizin acele gelmesini istediğiniz şeydir. İçinde elem dolu bir azabın bulunduğu bir rüzgârdır' dedi." ${ }^{\prime 23}$ Sonra bu bulut tarafindan gelen rîh-1 sarsar, ${ }^{124}$ yani soğuk veya gürültülü bir firtına ile helâk edildiler. ${ }^{125} \mathrm{Bu}$ olayı başı itibariyle inzar, sonu itibariyle bir helak mucizesi olarak sayabiliriz.

\subsection{Salih'in Devesi}

Salih peygamber Semûd kavmine gönderilmişti. Onlar kendisinin güvenilir bir kişi olduğunu, ${ }^{126}$ kendilerinden herhangi bir ücret istemediğinini ${ }^{127}$ bildikleri halde iman etmediler. Kendisinin büyülenmiş bir kişi olduğunu iddia edip eğer doğru söylüyorsa kendilerine bir mucize (âyet) getirmesi ${ }^{128}$ gerektiğini söylediler. Allah da onlara mucize olarak bir dişi deve verdi. ${ }^{129}$ "Sakın ona bir kötülük dokundurmayın, yoksa büyük bir günün azabı sizi yakalar" diyerek onları uyardı. Fakat onlar deveyi kestiler. Bundan pişman olsalar da azap onları yakaladı. ${ }^{130}$ Deve Semûd kavmi için bir inzar mucizesi idi. "Biz mucizeleri yalnızca korkutmak için göndeririz." 131 âyeti Semûd kavmine verilen deve mucizesi içindir.

\subsection{Misırlılara Verilen Afetler}

Hz. Musa Firavun ve kavmine mucize olara yed-i beyzasını ve asası vasıtasıyla bazı mucizeleri gösterdiği halde iman etmemekte ısrar ettiler. Sonuçta Yüce Allah kendilerine kıtlık, tufan, çekirge, haşere (buğday güvesi), kurbağa ve suyun kana dönüşmesi gibi afetleri verdi. ${ }^{132}$ Allah bunlarla onları korkuttu. Fakat yine iman etmemekte israr ettiler. Sonra Hz. Musa'ya bir gece İsrailoğulları'nı alıp Mısır'dan çıkmasını emretti. Asasını vurduktan sonra Kızıldeniz'de açılan kısımdan geçtikten sonra Firavun ve ordusu orada boğuldu. Afetler Firavun ve tabileri için birer inzar mucizesi idi.

\section{Helâk Mucizeleri}

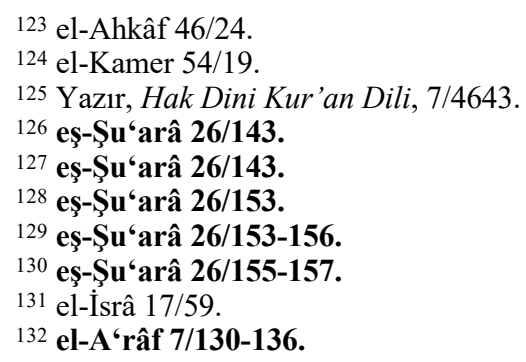

Turkish Academic Research Review - Türk Akademik Araştırmalar Dergisi 
Sadece inkâr etmekle yetinmeyip Peygamber'e ve ona inananlara zulmeden kavimleri Yüce Allah'ın olağanüstü bir şekilde helâk etmesine helâk mucizesi diyoruz. Kur'an'da, “Nuh, Âd ve Semûd kavimlerinin, İbrahim kavminin, Medyen halkinın ve altüst olan şehirlerin"133 zulümleri sebebiyle helâk edildikleri beyan edilmiştir. "Kimini de suda boğduk"134âyetiyle bunlara Firavun ve kavmi de eklenmiştir.

\subsection{Nuh Kavminin Helâki}

Nuh kavmi kendilerine gösterilen mucizelere rağmen inanmama konusunda 1srarcı olmakla yetinmeyip inananlara baskı yapmaya başlamışlar ve Nuh'tan etrafındakileri kovmasını istemişlerdi. ${ }^{135} \mathrm{~Hz}$. Nuh onlara, kendilerinden bir herhangi bir mal istemediğini, mükâfatını Allah’tan beklediğini, iman edenleri kovarsa kendisini Allah'tan başka kimsenin koruyamayacağını, Allah'ın hazinelerinin yanında olmadığını, gaybı bilmediğini, kendisinin melek de olmadığını, kendilerinin hor gördüğü inananları hor görürse gerçekten zulmetmiş olacağını söyledi. ${ }^{136}$ Onlar da "Ey Nûh! Bizimle tartıştın ve tartışmayı uzattın. Ĕger doğru söyleyenlerden isen, haydi kendisiyle bizi tehdit ettiğin azabr getir." 137 dediler. Yüce Allah, Nûh’a, “daha önce iman etmiş olanlardan başka, artık hiç kimse iman etmeyecek" buyurarak "gözetimimiz altında ve vahyimize göre gemiyi yap!"138 diye emretti. Nûh gemiyi yapmaya devam ederken, kavmi kendisiyle alay etmeye devam etti. ${ }^{139}$ Geminin yapımı bitince Nûh kendisine inananları ve bazı hayvanları gemiye aldı. Şiddetli bir şekilde yağmur yağdı, gözlerinin gördüğü her yer suyla kaplandı. Gemiye binmeyenler öldü. Allah yeryüzüne suyunu yutmasını, gökyüzüne de suyunu tutmasını emretti. Sular çekildi. Gemi Cudi'ye oturdu. ${ }^{140}$ Gemidekiler yere indi. Câhız'a göre tufan Nûh peygamberin en son ve en büyük mucizesi idi. ${ }^{141}$

\section{2. Âd Kavminin Helâki}

Yemen'de yaşayan Âd kavmine Hz. Hûd peygamber olarak gönderilmişti. Hz. Hûd kavmini Allah’tan başkasına ibadet etmemeye davet etmiş, onlar ise

\footnotetext{
133 et-Tevbe $9 / 70$.

134 el-'Ankebût 29/40.

135 Hûd 11/30.

136 Hûd 11/30-31.

137 Hûd 11/32.

138 Hûd 11/36-37.

139 Hûd 11/38.

140 Hûd $11 / 45$.

141 Câhı, Hz.Muhammed'in Nübüvvetinin Delilleri, 86-87. Nuh kavminin helaki hakkında geniş bilgi için bk. Resul Ertuğrul, "Kur'an'da Helâk Olan Kavimlerde Suç-Ceza Uyumu I", Bayburt Üniversitesi İlahiyat Fakültesi Dergisi 5 (2017), 171-174.
} 
"kendilerine apaçık bir beyine (mucize) getirmediği"142 iddiasında bulunmuşlar ve "Rabbimiz dileseydi elbette melekleri indirirdi; onun için biz sizinle gönderilen şeyleri inkâr ediyoruz" ${ }^{143}$ diyerek ona inanmayı reddetmişlerdi. Öyle anlaşılıyor ki onların, Hûd peygamberi getirmemekle itham ettikleri apaçık mucize, Hz. Hûd'un gösterdiği değil de, kendilerinin istediği mucize idi. Onlar Allah'tan kendilerine bir melek indirmelerini istemişti ve Yüce Allah tarafindan onların taleplerine müsbet cevap verilmemişti. Âd kavmi Hûd'u yalanlamaya devam etti. ${ }^{144}$ Allah da ceza olarak, onları yedi gece sekiz gün süren bir rüzgârla bulundukları yerde hurma kütükleri gibi yere sererek helâk etti. ${ }^{145}$ Âyetlerde Âd kavminin zulümleri sebebiyle helâk edildiği belirtilmiştir. ${ }^{146}$

\subsection{Semûd Kavminin Helâki}

Hz. Sâlih, Suriye ile Hicaz arasındaki Hicr bölgesinde yaşayan ve Kur'an'da ashâbü'l-Hicr ${ }^{147}$ adıyla geçen Semûd kavmine peygamber olarak gönderilmişti. Fakat onlar Sâlih peygamberi yalanlamaya devam ettiler. Sâlih peygamber onlara, "kendilerine gönderilmiş güvenilir bir peygamber olduğunu, Allah’a karşı gelmekten sakınıp kendisine itaat etmeleri" konusunda nasihatta bulundu ise de yeryüzünde fesat çıkarmaya devam ettiler. ${ }^{148}$ Sâlih peygamber "büyülenmiş"149 olmakla itham ettiler ve inatla ondan mucize istediler. O da "İşte size bir dişi deve!" diyerek mucize olarak gelen bu deve ile su hakkını onunla paylaşmalarını istedi. Ona bir kötülük yaparlarsa "büyük bir günün azabı sizi yakalar" diye onları ikaz etti. ${ }^{150}$ Müfessirler devenin mucize oluşu hususunda ittifak etmekle birlikte, kayadan çıkması yönüyle mi?, içtiği su kadar süt vermesi bakımından mı?, yoksa aşırı derecede yiyecek tüketmesi ve su içmesi yönüyle mi mucize olduğu hususunda ihtilaf edilmiştir. ${ }^{151}$

Semûd kavminden bozguncu dokuz kişi, ${ }^{152}$ deveyi kesip parçaladılar, sonra da Hz. Sâlih'i tehdit etmeye başladılar. ${ }^{153} \mathrm{O}$ da nihayet kendilerine üçüncü günün

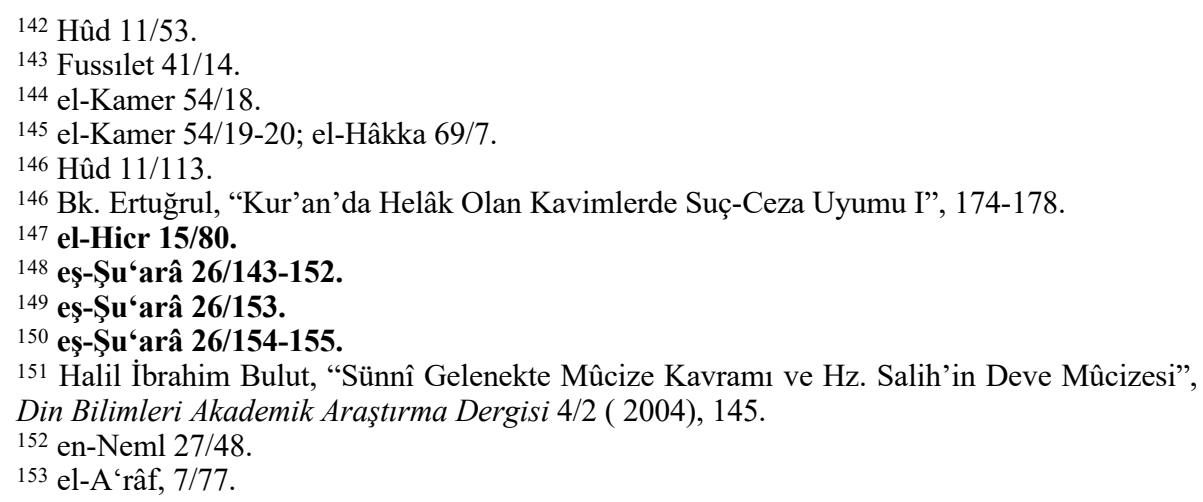

Turkish Academic Research Review - Türk Akademik Araştırmalar Dergisi 
sonunda istedikleri azabın geleceğini bildirdi. ${ }^{154}$ Dördüncü günün sabah vaktinde korkunç bir gürültü duyuldu. Ardından şiddetli bir yer sarsıntısıyla birlikte gelen taş yağmuru (racfe) ile helâk edildiler. ${ }^{155}$ Semûd kavminin helâk şekli bazı âyetlerde “ṣâ'ikatü'l- 'aẑâbi'l-hûn” (alçaltıca ve öldürücü ölüm, yıldırım) ${ }^{156}$ kavramlarıyla ifade edilmiştir. Muhtemelen bu taş yağmuru volkan patlaması sonucunda meydana gelmişti. Klasik tefsirlerde bu olay mahiyeti bakımından hissî mucizeye uygun şekilde dile getirilmiştir. ${ }^{157}$

\section{4. İbrahim Kavminin Helâki}

Halk arasında İbrahim kavminin helâki şöhret bulmamakla birlikte, "Onlara ... İbrahim kavminin..., ve alt üst olmuş şehirlerin haberi ulaşmadı mı?"158 âyetinden Nemrud ve kavminin de helâk edilen kavimler arasında olduğu anlaşılmaktadır. Ancak Kur'an ve hadislerde Nemrud ve kavminin nasıl helâk edildiğine dair bir bilgi bulunmamaktadır. Bununla birlikte Nemrud'un ölümüne bir sivrisineğin sebep olduğu hususunda yaygın bilgi vardır. Sa‘lebî ve Begavî’ye göre İbrahim kavminin helâki "nimetin kesilmesi ve Nemrud'un ölmesi"159 yoluyla gerçekleşmiştir. Öyle anlaşılıyor ki Hz. İbrahim’i ateşe atıp yakmak istedikten sonra Nemrud'un ömrü fazla uzun olmamış, onun ölümünden sonra çevresindekiler de durumu toparlayamamışlardı. Muhtemelen kıtlık ve iç isyan gibi sebeplerle dağılmışlardı.

\subsection{Lût Kavminin Helâki}

Hz. İbrahim'in yeğeni olan Lût, Sodom ahalisine peygamber olarak gönderilmişti. Sodomlular'dan Allah'a karşı gelmekten sakınmalarını, peygamber olarak kendisine itaat etmelerini, kadınlar yerine erkeklerle beraber olmanın büyük günah ve ahlaksızlık olduğunu hatırlatarak bu kötü fiilden vazgeçmeleri istedi, eğer vazgeçmezlerse Allah'ın azabının geleceğiyle onları korkuttu. Ancak Sodom halkı

\footnotetext{
154 Hûd 11/65.

155 el-A'râf, $7 / 78$.

156 Fussilet 41/17.

157 İbn Ebî Hâtim, Tefsîru'l-Kur'âni'l- 'Ażîm, 5/1516; Ebû Zeyd Abdurrahman b. Muhammed b. Mahlûf es-Se'âlibî, el-Cevâhiru'l-hisân fì tefsîri'l-Kur'ân. thk. Muhammed Ali Mu'avvid \& Âdil Ahmed Abdülmevcûd (Beyrut: Dâru İhyâi't-Türâsi'l-'Arabî, 1418). 3/52, Semud kavminin helâki hakkında geniş bilgi için bk. Resul Ertuğrul, "Kur'an'da Helâk Olan Kavimlerde Suç-Ceza Uyumu I”, Bayburt Üniversitesi Illahiyat Fakültesi Dergisi 5 (2017), 178-181.

158 et-Tevbe $9 / 70$;

${ }^{159}$ Ebû Muhammed el-Hüseyn b. Mes'ûd b. Muhammed b. Ferrâ el-Begavî, Me âlimü 't-tenzîl fì tefsîri'l-Kur'ân, thk. Abdürrezzâk el-Mehdî (Beyrut: Dâru't-Türâsi'l-'Arabî, 1420), 4/72; Ebû İshâk Ahmed b. Muhammed b. İbrahim es- Sa'lebî, el-Keşf ve'l-beyân 'an tefsîri'lKur'ân. thk. Ebû Muhammed b. 'Âşûr (Beyrut: Dâru İhyâi't-Türâsi'l-'Arabî, 1422/2002), $5 / 67$.
} 
Lût peygamberin tavsiyelerini dinlemedi. Sonunda "Yaptzklarımızın kötülüğü ve azaba uğrayacă̆ımız konusunda) doğru söyleyenlerden isen Allah'ın azabını bize getir"160 diyerek inkârlarını ve sapıklıklarını sürdürmeye devam ettiler. Hz. Lût onlardan o kadar bıkmışıı ki, sonunda "Ey Rabbim! Şu bozguncu kavme karşı bana yardim et, dedi." 161 Akabinde Allah insan suretinde baz1 melekleri kendisine gönderdi. Sodom halkı onlara da kötülük yapmak istediler. Melekler Lût ve ona inananları kurtard, Sodom ahalisi ise (taş) yağmuru ${ }^{162}$ ve gökten gelen bir azap ${ }^{163}$ ile helâk edildiler. ${ }^{164}$

\subsection{Medyen Halkının Helâki}

Hz. Şuayb, Medyen halkının peygamberiydi. Onları Allah'ı inanıp putları inkâr etmeye, kendisini peygamber olarak tanıyıp Allah'ı kulluk etmeye, ${ }^{165}$ ölçü ve tartıda doğru olmaya, insanlar arasında adaletle hükmetmeye, haksızlık yapmamaya, yeryüzünde bozgunculuk çıkarmamaya ${ }^{166}$ davet etti. Ancak Medyenliler onu dinlemediler, tavsiyelerine uymadılar. Sonunda Şuayb peygamber, yapılan ikazlara kulak asmamaları halinde Nûh, Hûd, Sâlih ve Lût peygamberlerin kavimleri gibi başlarına bir felaket geleceğini bildirdi. ${ }^{167}$ Fakat onlar Hz. Şuayb'ın uyarılarını dinlemedikleri için şiddetli bir yer sarsıntısı (racfe), ${ }^{168}$ şiddetli bir ses (sayha) ${ }^{169}$ ve gölge günü azabı (azâabu yevmi'z-zulle $)^{170}$ ile helâk edildiler. ${ }^{171} \mathrm{~Hz}$. Şuayb ve ona inananlar ise bu helâkten kurtuldular. Medyenlileri helak eden racfe ve sayhanın, bir volkan patlaması olduğu ifade edilmiştir. ${ }^{172}$

\footnotetext{
160 el-Ankebût 29/29.

161 el-Ankebût 29/30

162 el-A'râf 7/84; eş-Şuarâ 26/173; en-Neml 27/58.

163 el-Ankebût 29/34.

164 Lût kavminin helâki hakkında geniş bilgi için bk. Resul Ertuğrul, "Kur'an'da Helâk Olan Kavimlerde Suç-Ceza Uyumu II", Bayburt Üniversitesi İlahiyat Fakültesi Dergisi 7 (Haziran 2018), 145-173.

165 eş-Şu'arâ 26/176-179; el-A'râf 7/85.

166 el-A'râf 7/85-86, 90; Hûd 11/84-86; eș-Su'arâ 26/181-183.

167 Hûd 11/89.

168 el-A'râf 7/91; el-Ankebût 29/37.

169 Hûd 11/94.

170 eş-Su' arâ 26/189.

171 et-Tevbe $9 / 70$.

172 Medyen halkının helâki hakkında geniş bilgi için bk. Ertuğrul, "Kur'an'da Helâk Olan Kavimlerde Suç-Ceza Uyumu II”, 152-154.
}

Turkish Academic Research Review - Türk Akademik Araştırmalar Dergisi 


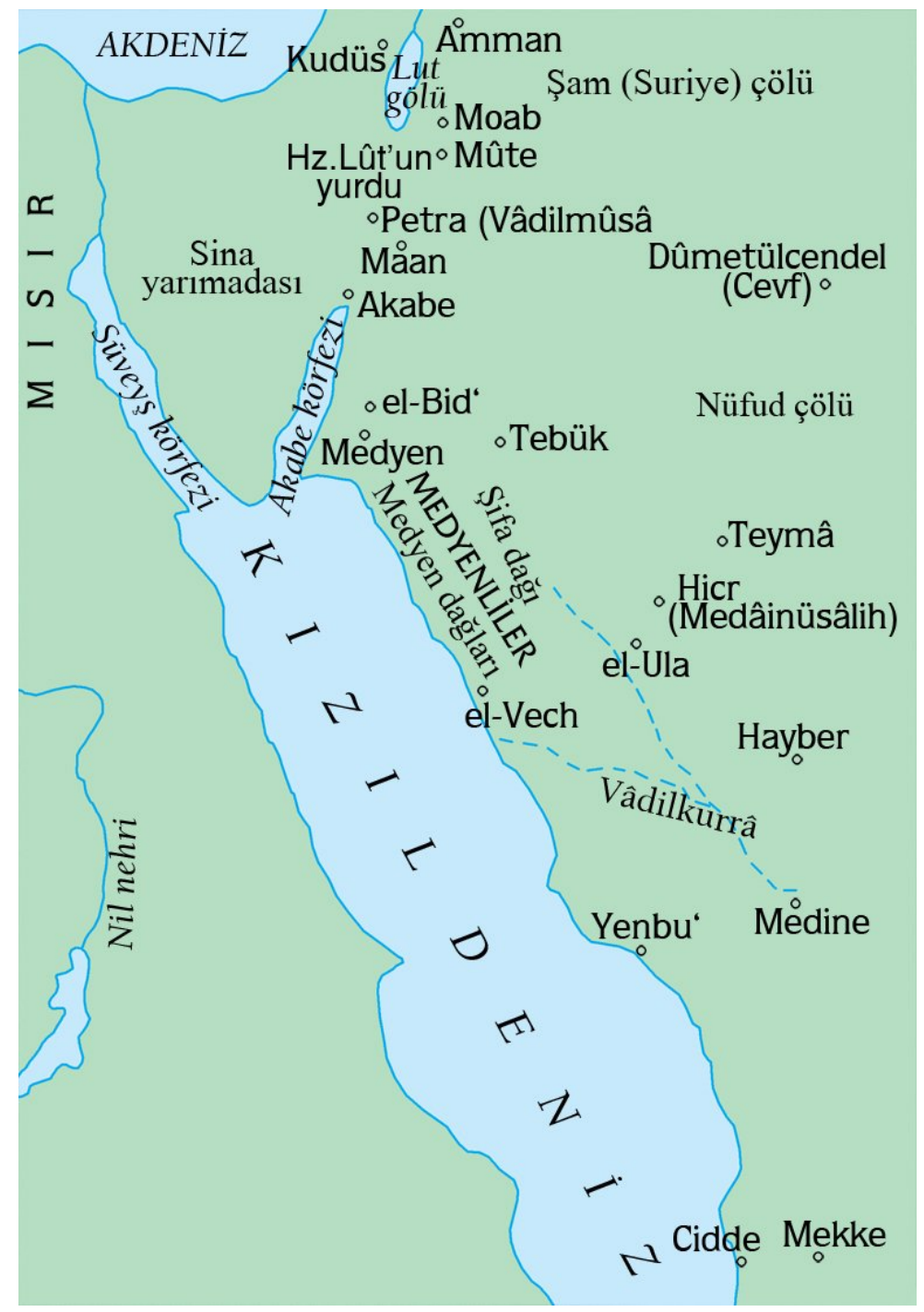

\subsection{Firavun ve Kavminin Helâki}

Helâk edilen kavimlerden biri de Hz. Musa’ya inanmamakta direnen, kendisini öldürmeye çalışan ve İsrailoğulları'na da çeşitli zulümler yapan Firavun ve tabileridir. ${ }^{173}$

Helâk edilen kavimlerin sadece inkârcı olmaları sebebiyle değil, bunun ötesinde peygamberlere ve inananlara zulmetmeleri ve Allah'ın kudretini test etmeye kalkışmaları sebebiyle helâk edildikleri anlaşılmaktadır.

\subsection{Ashâbü'l-Karye'nin Helâki}

${ }^{173}$ Firavun ve kavminin helâki hakkında geniş bilgi için bk. Ertuğrul, "Kur'an'da Helâk Olan Kavimlerde Suç-Ceza Uyumu II”, 154-159. 
Köy ve küçük kasabalara Arapçada karye denilmektedir. Kur'an'da Mekke ve Kudüs gibi büyük yerleşim merkezleri için de karye kelimesinin kullanıldığ 1 görülmektedir. "Ashâbü'l-karye" tabiriyle böyle bir yerleşim merkezinde oturan insanlar kastedilmiştir. Yüce Allah'ın beyanına göre “ashabü’l-karye”ye önce iki elçi (mürsel) gönderilmiş, ancak bu topluluk onları dinlememiştir. Daha sonra Yüce Allah üçüncü bir elçi göndererek bu iki elçiye destek vermiştir. Şehrin öbür ucundan bir adam gelerek halkına bu elçilere tabi olmalarını istemiş, ancak şehir halkı bu elçileri dinlemediği gibi bu adamı da öldürmüşlerdi. Netice itibariyle Allah'ın elçilerine inanmayan ve kendilerinden olan mümin bir kişiyi öldüren bu topluluk müthiş bir sesle (sayha) helâk edilmiştir. ${ }^{174}$

\section{9. İmanın Takviyesi}

\section{1. Âhirete İmanın Takviyesi}

Kur'an'daki bazı örnekler ahirete iman meselesinin geçmiş ümmetlerde mucize yoluyla takviye edildiği anlaşılmaktadır. Bunun en açık örneği Ashab-1 Kehf olayidir.

Kehf Sûresi'nin 9-26. âyetlerinde, halk arasında Yedi Uyuyanlar diye bilinen Ashâb-ı Kehf olayı anlatılmaktadır. Buna göre Allah'ın varlığına ve birliğine inanan ve tam olarak ne zaman ve nerede yaşadıkları tam olarak bilinmeyen bir grup genç, putperest olan kavminin inançlarına karşı çıkmış, sonuçta kavmi taşlanarak öldürülmekten veya zorla din değiştirmekten kurtulmak için bir mağaraya sığınmışlardı. Yanlarındaki köpekleriyle birlikte bu gençler sığındıkları mağarada derin bir uykuya dalmışlar ve 309 yıl sonra uyanmışlardı. ${ }^{175}$ Yüce Allah bu olayı insanlara kıyametin hak olduğunu bildirmek üzere anlattığını beyan etmektedir: “Böylece biz, (insanlarl) onların halinden haberdar ettik ki, Allah'ın va'dinin hak olduğunu ve kıyametin gerçekleşmesinde de hiçbir şüphe olmadığını bilsinler..."176

Hz. İbrahim'in parçalayıp her parçasını bir dağın başına koyduğu kuşların çağırdığı zaman kendisine uçarak gelmesi, Hz. Musa zamanında öldürülen bir kişinin bedenine kesilen hayvanın bir parçasının vurulmasıyla dirilip katilini haber vermesi ve Hz. İsa'nın ölüleri diriltmesi mucizeleri de bir yönüyle âhirete imanı takviye eden mucizelerdir.

174 Yâsîn 36/13-29. Ashâbü'l-karye hakkında geniş bilgi için bk. Abdullah Aydemir, “Ashâbü'l-Karye”, Türkiye Diyanet Vakfi İslâm Ansiklopedisi (İstanbul: TDV Yayınları, 1991), 3/468-469.

175 el-Kehf 18/9-26. Geniş bilgi için bk. İsmet Ersöz, “Ashab-1 Kehf”, Türkiye Diyanet Vakfi İslâm Ansiklopedisi (İstanbul: TDV Yayınları, 1991), 3/466.

176 el-Kehf 18/21.

Turkish Academic Research Review - Türk Akademik Araştırmalar Dergisi 
İnşikak-1 kamer mucizesinin de ahirete imanı destekleyici bir özelliği vardır. Çünkü birkaç âyet sonra kıyametin kopuş sahnelerinden söz edilir. Dolayısıyla bu mucize aynı zamanda ahiretin de kesin olarak var olacağını gösterir.

\subsection{Mü’minlerin İmanını Takviye}

İnşikâk-1 kamer mucizesinin buna örnek olduğu söylenebilir. Kamer suresinin birinci âyetinde geçen "İkterabeti's-sâ‘a ve'nşaḳkạ'l-ḳamer"177 ifadesi müfessirler tarafından genellikle "Kıyamet yaklaştı, Ay yarıldı" şeklinde anlaşılmıştır. Kelâmcılar da Ayın ikiyi bölünmesi hadisesini Hz. Peygamber'in en önemli hissî mucizesi olduğunu ifade etmişlerdir. Son dönemde yaşayan bazı müfessirler ve araştırmacılar ise inşakka fiilinin gelecek zaman kipiyle anlaşılmasının Kur'an mantığı açısından daha isabetli olacağını savunmaktadırlar. $\mathrm{Bu}$ konudaki üçüncü görüş ise ayetin mecaz anlamında olup gerçeğin açık ve belirgin olduğu anlamına geldiği şeklindedir. ${ }^{178}$

Başta Buharî ve Müslim olmak üzere birçok hadis müellifi tarafından rivayet edilen inşikak-1 kamer rivayetleri sahabeden Ali b. Ebû Tâlib, Abdullah b. Mes'ûd, Abdullah b. Ömer, Abdullah b. Abbas, Enes b. Mâlik, Cübeyr b. Mut'im ve Huzeyfe b. Yemân'dan gelmiştir. ${ }^{179}$ Tefsirciler ve kelamcılar çoğunlukla hicretten önce Mekke'de meydana gelen olayın müşriklerin talebi üzerine gerçekleştiğini ileri sürseler de, sadece Enes b. Mâlik'ten gelen rivayetlerde olayın müşriklerin talebi üzerine gerçekleştiği ifade edilir, diğer sahâbîlerden gelen rivayetlerde böyle bir kayıt bulunmamaktadır. Hz. Enes'in o sırada Medine'de küçük bir çocuk olduğu bilinmektedir. Onun bu rivayeti diğer sahabîlerden işittiği açıktır. Ancak onların rivayetlerinde böyle bir kayıt yoktur. Bu kaydın olmaması olayın bir hidayet ve irşad mucizesi olmadığını, genelde nusret mucizesine dahil edilebileceğini, özelde ise müminlerin imanını takviye için meydana geldiğini söyleyebiliriz.

Diğer taraftan bazı araştırmacılar Kur'an'da müşriklerin ısrarlı bir şekilde Hz. Peygamber'den mucize talep etmelerine karşıllk bu taleplerine olumsuz cevap verildiğini dikkate alarak, Hz. Peygamber'in tek hidayet mucizesinin Kur'an olduğunu, Kur'an'ın dışında herhangi bir hidayet mucizesinin bulunmadığını ileri sürmektedirler. ${ }^{180}$ Biz de hidayet mucizesiyle sınırlı kalmak kaydıyla bu görüşü

\footnotetext{
177 el-Kamer 54/1.

178 Bulut, Nübüvvetin İspatında Mucize, 205-212; İlyas Çelebi, "İnşikâku'l-Kamer”, Türkiye Diyanet Vakfi İslâm Ansiklopedisi (İstanbul: TDV Yayınları, 2000), 22/341-345.

179 Konuyla ilgili hadislerin tahlili için bk. Hüseyin Akgün, "İnşikâk-1 Kamer Hâdisesi (Rivayetlerin Aslu'l-Hadîs ve Hadis Coğrafyası Açısından Ele Alınması)", Siyer Araştırmaları Dergisi 3 (Hariran 2018), 33-54.

180 Bulut, Nübüvvetin İspatında Mucize, 202.
} 
kabul ediyoruz. Ancak Hz. Peygamber'in hidayet mucizesi cinsinden hissî mucizesinin olmaması, başka maksatlarla meydana gelecek olan hissî mucizelerinin olmamasını gerektirmez. Bu araştırmada görüldüğü üzere gayesi bakımından mucizeleri dokuz kısma ayırmak mümkündür. Hz. Peygamber'in gayesi bakımından hidayet, yapısı bakımından hissî mucize kısmına dahil olan bir mucizesi olmasa dahi; gayesi bakımından diğer mucize kısımlarına dahil olan, ancak yapısı bakımındın hissi mucize kısmına giren mucizeleri vardır. Müfessirlerin ve kelâmcıların Kur'an'da mucize olarak kabul ettikleri olayları bu sınıflara dahil etmek mümkündür.

\begin{tabular}{|l|l|l|}
\hline Sıra & Gayesi Bakımından Kur'an'da Mucize Çeşitleri & Miktarı \\
\hline 1 & I'lâm/Bildirim Mucizeleri & 4 \\
\hline 2 & Hidayet/İrşad Mucizeleri & 9 \\
\hline 3 & Nusret Mucizeleri & 7 \\
\hline 4 & İkram Mucizeleri & 20 \\
\hline 5 & İsmet Mucizeleri & 9 \\
\hline 6 & İkaz Mucizeleri & 3 \\
\hline 7 & İnzar Mucizeleri & 9 \\
\hline 8 & Helak Mucizeleri & 8 \\
\hline 9 & İman Esaslarını Takviye Mucizeleri & $\mathbf{7 1}$ \\
\hline & Toplam & \\
\hline
\end{tabular}

Bu tablo takribî bir durumu ifade eder. Zira burada yer alan bazı olayların bazı müfessirlere göre mucize sayılmaması veya olağanüstü nitelikli görmediğimiz için makalede yer vermediğimiz bazı olayların ise mucize sayılması mümkündür. Diğer taraftan aynı olayın birkaç amacı olması sebebiyle onu birden fazla yerde saymak da mümkün görünmektedir.

\section{Sonuç}

$\mathrm{Bu}$ çalışmada, Kur'an'da zikredilen ve müfessirler tarafından genellikle mucize olduğu kabul edilen yetmiş dolayında olay tespit edilmiştir. Bu olaylardan birkaçının olağanüstü olup olmadığı klasik müfessirler tarafından da tartışılmıştır. Ancak büyük çoğunluğunun hâriku't-tabîa olduğu hususunda ittifak edilmiştir. Tabiî olarak mucizenin tabiat kanunlarına aykırı olamayacağını iddia edenler bu ittifaka dahil değildir. 
Kelâmcılar mucizelerin daha çok yapısı itibarıyla kısımları üzerinde durmuş, gayesi bakımından taksimatına pek önem vermemiş ve mucizenin ana gayesinin "peygamber olduğunu iddia eden bir zatın nübüvvetini ispat etmek" olduğunu ileri sürmüşlerdir. Ancak mucize örnekleri tek tek incelendiğinde mucizenin ana gayesinin nübüvveti ispat vasıtası olduğunu söylemek bir hayli zor görünmektedir. Kur'an'da zikri geçen yetmiş kadar mucizeden dördünün bir zata peygamber olduğunu bildirmek; dokuzunun bir peygamberin muhatabına peygamber olduğunu ispat; yedisinin inananlara yardım; yirmisinin peygambere yardım; dokuzunun peygamberi, kutsal mekânları ve inananları korumak; üçünün peygamberi veya inananları uyarmak; dokuzunun inanmamaları halinde inkârcıları şiddetli bir azabın geleceğiyle korkutmak; sekizinin inkârcıları helâk etmek; birincil amaç olarak ikisinin ikincil amacıyla birlikte beşinin iman esaslarını takviye etmek maksadıyla gerçekleştiği anlaşılmaktadır.

Gayesi bakımından dokuz kısma ayrılan mucizeleri daha da indirgemek mümkündür: İ'lâm ve hidayet mucizelerini "bir zatın peygamber olduğunu bildirme ve ispat"; nusret, ikram, ismet ve ikaz mucizelerini "peygamberlere ve inananlara yardım"; inzar ve helâk mucizelerini "inkârcıları korkutma ve helâk etme" başlıkları altında toplayabiliriz. Buna göre mucizelerin gayesini, "peygamberin nübüvvetini ispat", "inananlara yardım"; "münkirleri helak" veya "İman esaslarını takviye" şeklinde dört başlık altında incelemek mümkün görünmektedir.

Mucizeleri dokuz sınıfa ayırmış olmakla birlikte herhangi bir mucizenin tamamen tek bir sınıfa irca edilmesinin mümkün olmadığı da görülmektedir. Bunun üç sebebi vardır:

a. Herhangi bir mucize doğrudan hidayet/irşad mucizesi sayılmasa bile, netice itibariyle her mucize bir zatın peygamber olduğunu gösterdiğinden dolaylı olarak bütün mucizeler hidayet mucizesi hükmündedir. Mesela bir mucizenin temel amacı inkârcıları helâk etmek olabilir. Ancak dolaylı olarak bu olay bir zatın peygamber olduğunu ispat edici bir özellik kazandığından aynı zamanda hidayet mucizesi sayılmaktadır. Fakat helak sebepleri zuhur ettikten sonra iman kabul edilmez.

b. Bazen aynı mucize farklı durumlarda farklı amaçlarla ortaya çıkmaktadır. Mesela yed-i beyza ve asa mucizeleri ilk önce Hz. Musa'ya kendisinin peygamber olduğunu bildirmek (i'lâm) maksadıyla ortaya çıkarken, Firavun ve tâbilerine gösterildiklerinde hidayet/irşad amacını taşımaktadırlar. 
c. Bazı mucizelerin birincil amaçlarının yanı sıra ikincil amaçları da vardır. Mesela parçalanmış ve her parçası bir dağın tepesine konulmuş olan kuşların Hz. İbrahim'in onları çağırmasıyla gelmelerinin birinci amacı peygambere ikram; ikincil amacı ise inananların ahirete imanlarını takviyedir.

Toplam mucizeler içinde nusret mucizelerinin çoğunlukta olduğu dikkate alındığında mucizelerin en önemli amacının müminlere yardım olduğunu söyleyebiliriz. Bununla birlikte hangi mucize kısmına girerse girsin netice itibariyle bütün mucizelerin bir zatın peygamber olduğunu ispat etmesi gibi bir fonksiyonu olduğundan, müfessirler ve kelamcılar gibi biz de mucizenin en önemli amacının bir zatın nübüvvetini ispat olduğunu söyleyebiliriz. Ancak bu hususu tek amaç gibi ele almanın da doğru olmadığını vurgulamamız gerekir.

Mucizenin temel amacının hidayet ve irşad olduğunu ileri sürmek, diğer mucize çeşitlerini izah edilemez hale getirir. Çünkü hidayet mucizelerinin temel özelliklerinden birisi tehaddîdir. Hidayet mucizelerinin dışındaki mucizelerin böyle bir özelliği yoktur. Sözgelimi Hz. Musa'nın Tuva vadisinde bulunduğu sırada elini koynuna sokup çıkardığında elinin bembeyaz olması ve asanın yılana dönüşmesi mucizelerinde tehaddî yoktu; ancak aynı mucizeler Firavun ve tabilerine gösterildiği zaman bunlarda tehaddî vardı. Peygamberlerin elinde zuhur eden bütün olağanüstü olaylar dikkate alındığında, mucizenin en temel özelliğinin bir peygamberin elinde zuhur etmesi ve olağanüstü/harikulâde bir niteliğe sahip olması olduğunu söyleyebiliriz. Olağanüstülüğü de sadece tabiatı ihlal edici/hâriku't-tabîa nitelikte olmakla sınırlamamak gerekir. Nitekim haberî mucizelerde olağanüstü olan, olayın kendisi değil, beşerî imkânlarla gerçeğe ait bilgiye ulaşma imkânı olmadığı halde peygamberlerin doğru bilgiyi vermiş olmalarıdır.

Bütün yardım mucizeleri tehaddî özelliğine sahip olmamakla birlikte olağanüstü olma özelliğine sahiptirler. Bir peygamberin elinde zuhur etmeleri sebebiyle bunları da mucize olarak kabul etmemiz gerekir.

Yapısı bakımından mucizeler hissî, haberî ve aklî olmak üzere üç kısma ayrılmışlardır. Müşriklerin Hz. Peygamber'den hissî mucize talepleri karşısında Cebâb-1 Allah'ın onların bu taleplerini olumsuz karşılaması ve nazarları Kur'an'a çevirmesi, Hz. Peygamber'in Kur'an'dan başka bir mucizesinin bulunmadığını göstermez. Sadece amacı itibariyle hidayet mucizesi kabilinden bir hissî mucizesi olmadığı söylenebilir. Çalışmamızda gerek diğer peygamberlere, gerekse $\mathrm{Hz}$. Peygamber'e ait olsun hidayet mucizesinin dışında birçok hissî mucizesinin bulunduğu açıkça görülmektedir.

Turkish Academic Research Review - Türk Akademik Araştırmalar Dergisi 
Mucize konusunun anlaşılması için onu hem yapısı, hem gayesi itibariyle değerlendirmek gerekir. Sadece yapısı itibariyle yapılan değerlendirmeler bizi yanlış sonuçlara götürebilir.

Kelâmcıların mucize konusunda tehaddî şartını ileri sürmeleri pek çok hârikulâde olayın mucize kapsamının dışında kalması sonucunu doğurmaktadır. Fakat bu durumda mucize sayılmayan olaylara ne ad verileceğini de tasrih etmemişlerdir. Diğer taraftan mucize tanımlarına tehaddî şartını koymakla birlikte, mucize için verdikleri örneklere bakıldığında tehaddî özelliğini taşımayan pek çok olağanüstü olaya mucize dedikleri görülmektedir. Bu da bir çelişkidir. Bu çelişkiyi ortadan kaldırmak için mümkün olduğu kadar olağanüstü nitelikli olayları mucize kapsamında değerlendirmek gerekir.

\section{Kaynakça}

Ahmed b. Hanbel. el-Müsned. 8 cilt. Misır: Müessesetü Kurtuba, ts.

Akgün, Hüseyin. "İnşikâk-1 Kamer Hâdisesi (Rivayetlerin Aslu'l-Hadîs ve Hadis Coğrafyası Açısından Ele Alınması)". Siyer Araştırmaları Dergisi 3 (Hariran 2018), 33-54.

Atik, Bilal. Kur'an'a Göre Değişmeyen Sünnetullah Olarak Mucize Olgusu. Ankara: Ankara Üniversitesi, Sosyal Bilimler Enstitüsü, Doktora Tezi, 2018.

Bakkal, Ali. "Hz. Peygamber'in Düşmanlarından Korunması". Diyanet İlmî Dergi 56/2 (2020), 493-522.

Begavî, Ebû Muhammed el-Hüseyn b. Mes'ûd b. Muhammed b. Ferrâ el-. Me 'âlimü't-tenzîl fì tefsîri'l-Kur'ân. thk. Abdürrezzâk el-Mehdî. Beyrut: Dâru't-Türâsi'l-'Arabî, 1420.

Beydâvî, Nâsı̈üddin Ebû Saîd Abdullah b. Ömer b. Muhammed eş-Şîrâzî. Envâru'ttenzîl ve esrârü't-te'vîl. thk. Muhammed Abdurrahman el-Mar'aşlî. Beyrut: Dâru İhyâi't-Türâsi'l-'Arabî, 1418.

Buhârî, Muhammed b. İsmail. Șahịhu'l-Buhârrî. İstanbul: Çağrı Yayınları, 1981.

Bulut, Halil İbrahim. "Mûcize". Türkiye Diyanet Vakfi İslâm Ansiklopedisi. 30/350352. İstanbul: TDV Yayınları, 2005. 
Bulut, Halil İbrahim. Nübüvvetin İspatında Mucize. İstanbul: Araştırma Yayınları,2016.

Bulut, Halil İbrahim. "Sünnî Gelenekte Mûcize Kavramı ve Hz. Salih'in Deve Mûcizesi”. Din Bilimleri Akademik Araştırma Dergisi 4/2 (2004): 137-150.

Câhız, Ebû Osman Amr b. Bahr b. Mahbûb. Hz.Muhammed'in Nübüvvetinin Delilleri (Hucecü'n-nübüvve) (metin-çeviri). çev. İbrahim Halil Erdoğan. Kayseri: Kimlik Yayınları, Kayseri 2017.

Cürcânî, Seyyid Şerif. Şerhu'l-Mevâkıf: Mevâkıf Şerhi (metin-çeviri). çev. Ömer Türker. 3 Cilt. İstanbul: Türkiye Yazma Eserler Kurumu Başkanlığı, 2015.

Çelebi, İlyas. “İnşikâku'l-Kamer”. Türkiye Diyanet Vakfi İslam Ansiklopedisi. 22/341-345. İstanbul: TDV Yayınları, 2000.

Ersöz, İsmet. “Ashab-1 Kehf”. Türkiye Diyanet Vakfi İslâm Ansiklopedisi. 3/465467. İstanbul: TDV Yayınları, 1991.

Ertuğrul, Resul. “Kur’an’da Helâk Olan Kavimlerde Suç-Ceza Uyumu I”, Bayburt Üniversitesi İlahiyat Fakültesi Dergisi 5 (2017), 164-185.

Ertuğrul, Resul. Kur’an’da Helâk Olan Kavimlerde Suç-Ceza Uyumu II”, Bayburt Üniversitesi İlahiyat Fakültesi Dergisi 7 (Haziran 2018), 145-173.

Fahreddin er-Râzî Ebû Abdullâh Muhammed b. Ömer b. el-Hasan b. el-Hüseyn etTeymî. Mefâtîhu'l-gayb - et-Tefsîru'l-kebîr. Beyrut: Dâru İhyâi’t-Türâsi'lArabî, 1420.

Fahreddin er-Râzî. el-Meṭâlibü'l-'âliye mine'l- 'ilmi'l-ilâhî. thk. Ahmed Hicâzî esSekkā. Beyrut: Dâru'l-Kitâbi'l-Arabî, 1987.

Fayda, Mustafa. "Fil Vak'ası”. Türkiye Diyanet Vakfi İslâm Ansiklopedisi. 13/70-71. İstanbul: TDV Yayınları, 1996.

Ferrâ, Ebû Zekeriyya Yahya b. Ziyâd b. Manzûr, Me 'âni'l-Kur'ân. thk. Ahmed Yusuf en-Necâtî vd.. Misır: Dâru'l-Misriyye, 1955.

Harman, Ömer Faruk. "Hâbil ve Kâbil". Türkiye Diyanet Vakfi İslâm Ansiklopedisi. 14/376-378. İstanbul: Türkiye Diyanet Vakfı Yayınları, 1996.

Harman, Ömer Faruk. "Îsâ". Türkiye Diyanet Vakfi İslâm Ansiklopedisi. 22/ 465 472. İstanbul: TDV Yayınları, 2000.

Harman, Ömer Faruk. "Ya'kûb", Türkiye Diyanet Vakfi İslâm Ansiklopedisi. 43/274-276. İstanbul: TDV Yayınları, 2313.

İbn 'Atıyye, Ebû Muhammed Abdülhak b. Gâlib b. Abdirrahman b. Temâm b. 'Atıyye el-Endelûsî. el-Muharreru'l-vecîz fî tefsîri'l-Kitâbi'l-'Azîz. thk. Abdüsselâm Abdüşşâfî Muhammed. Beyrut: Dâru'l-Kütübi’l-‘İlmiyye, 1422.

Turkish Academic Research Review - Türk Akademik Araştırmalar Dergisi https://dergipark.org.tr/tr/pub/tarr 
İbn Ebî Hâtim, Ebû Muhammed Abdurrahman b. Muhammed b. İdris b. el-Münzir. Tefsîru'l-Kur'âni'l-'Azîm. thk. Es'ad Muhammed et-Tayyib. Suudi Arabistan: MektebetüNizâr Mustafa el-Bâz, 1419.

Kādî Abdülcebbâr b. Ahmed. Teșbîtü delâili'n-nübüvve (Mucizelerle Hz. Peygamber'in Hayatı). çev. M. Şerif Eroğlu \& Ömer Aydın. İstanbul: Türkiye Yazma Eserler Başkanlığı, 2017.

Karaman, Hayrettin vd.. Kur'ân-ı Kerim ve Açıklamalı Meâli. Türkiye Diyanet Vakfi Yayınları, Ankara 2007.

Karaman vd. Kur'an Yolu - Türkçe Meal ve Tefsir. Ankara: Diyanet İşleri Başkanlığı Yayınları, 2007.

Kitab-1 Mukaddes, Eski ve Yeni Ahit. İstanbul 1998.

Mâtürîdî, Ebû Mansûr Muhammed b. Muhammed b. Mahmûd. Te'vîlâtü Ehli'sSünne. thk. Mecdî Bâselîm. Beyrut: Dâru'l-Kütübi'l-'İlmiyye, 1426/2005.

Mâverdî, Ebü'l-Hasan Ali b. Muhammed b. Muhammed. en-Nüket ve'l-'uyûn. Beyrut: Dâru'l-Kütübi'l-'İlmiyye, t.y.

Müslim, Ebü’l-Hüseyin Müslim b. Haccâc el-Kuşeyrî. Șahîhu Müslim. İstanbul: Çağrı Yayınları, 1981.

M. Sait Özervarlı, "Hârikulâde", Türkiye Diyanet Vakfı İslâm Ansiklopedisi. 16/181183. İstanbul: TDV Yayınları, 1997.

Öztürk, Mustafa. “Mü’tefike”. Türkiye Diyanet Vakfi İslâm Ansiklopedisi. 32/185186. İstanbul: TDV Yayınları, 2006.

Pezdevi, İmam Ebu Yusr Muhammed. Ehl-i Sünnet Akaidi. çev. Şerafeddin Gölcük. İstanbul: Kayıhan Yayınları, 1980.

Sa'lebî, Ebû İshâk Ahmed b. Muhammed b. İbrahim es-. el-Keşf ve’l-beyân 'an tefsiri'l-Kur'ân. thk. Ebû Muhammed b. 'Âşûr. Beyrut: Dâru İhyâi’t-Türâsi'l'Arabî, 1422/2002.

Se‘âlibî, Ebû Zeyd Abdurrahman b. Muhammed b. Mahlûf. el-Cevâhiru'l-ḥıân fî tefsîri'l-Kur'ân. thk. Muhammed Ali Mu'avvid \& Âdil Ahmed Abdülmevcûd. Beyrut: Dâru İhyâi’t-Türâsi’l-'Arabî, 1418.

Semerkandî, Bạ̣ru’l- 'ulûm. Ebü'l-Leys Nasr b. Muhammed b. Ahmed b. İbrahim. Beyrut: 1413/1993.

Taberî, Ebû Ca'fer Muhammed b. Cerîr. Câmi 'u'l-beyân fi te’vîli'l-Kuru'ân. nşr. Ahmed Muhammed Şakir. Kâhire: Müessesetü'r-Risâle, 1420/2000.15/297.

Ulutaş, Yasin. İslâm Düşüncesinin Teşekkül Döneminde Mucize Anlayışları. Kahramanmaraş: Kahramanmaraş Sütçü İmam Üniversitesi, Sosyal Bilimler Enstitüsü, Doktora Tezi, 2018. 
Yavuz, Salih Sabri. "Mi“rac”. Türkiye Diyanet Vakfi İslâm Ansiklopedisi. 30/132135. İstanbul: TDV Yayınları, 2005.

Yavuz, Yusuf Şevki. "Vahiy". Türkiye Diyanet Vakfi İslâm Ansiklopedisi. 42/440443. İstanbul: TDV Yayınları, 2012.

Yazır, Elmalılı M. Hamdi. Hak Dini Kur'an Dili. İstanbul: Eser Kitabevi, t.y.

Yeprem, Mustafa Saim. Mâtürîdî’nin Akîde Risâlesi ve Şerhi. Ankara: Türkiye Diyanet Vakfı Yayınları, 2011.

Zemahşerî, Ebü'l-Kâsım Mahmud b. Amr b. Ahmed. el-Keşşâf 'an hakẩiḳ-ı ġavâmiḍı't-te'vîl. Beyrut: Dâru'l-Kitâbi'l-‘Arabî, 1407.

Turkish Academic Research Review - Türk Akademik Araştırmalar Dergisi https://dergipark.org.tr/tr/pub/tarr 